\title{
Building Information Modelling Plan of Work for Managing Construction Projects in Egypt
}

\author{
KF Amin and *Fonbeyin Henry Abanda
}

\begin{abstract}
Published online: 31 December 2019
To cite this article: KF Amin and Fonbeyin Henry Abanda (2019). Building Information Modelling Plan of Work for Managing Construction Projects in Egypt. Journal of Construction in Developing Countries, 24(2): 23-61. https://doi.org/10.21315/ jcdc2019.24.2.2.

To link to this article: https://doi.org/10.21315/jcdc2019.24.2.2

Abstract: The Royal Institute of British Architects (RIBA) Plan of Work (PoW) together with Building Information Modelling (BIM) guidance documents, developed in the UK, are commonly used in Egypt and the Middle East. However, efforts from academics publishing articles about the experiences of the adoption of such BIM standards in Egypt have been very limited. This research investigates the use of a BIM-RIBA POW in the construction industry in Egypt. The research aim was achieved through literature review and collecting qualitative data from industry practitioners. Focus group interviews was used to collect qualitative data, then analysed through consecutive stages of transcription, coding and structuring. The main finding of this study is that integrating the RIBA PoW in Egypt would be beneficial only if the established construction activities have been further detailed and linked to BIM concepts. A BIM-RIBA PoW has been developed through the identification of main BIM objectives and activities in each stage in the project lifecycle.
\end{abstract}

Keywords: BIM, Construction projects, Egypt, Integrated project delivery, RIBA Plan of Work

\section{INTRODUCTION}

For some time now, housing and infrastructure projects have become the main priority for the Egyptian government (Bank Audi, 2016). The construction sector accounted for 4.8\% of Egypt's gross domestic product (GDP) in 2015 (Bank Audi, 2016). The Egyptian government is currently undertaking several large projects in power, residential, retail and infrastructure fields. A Power Supply Programme 20102020 has been developed with the aim of adding 30,000 megawatts to the country's current electrical capacity. The programme includes several renewable energy generation projects in addition to a nuclear power plant, with an annual investment in excess of GBP 3 billion (Gov.uk, 2015). In the infrastructure field, ports, factories and logistics centres are being developed in the Suez Canal Zone Project with an estimated worth of about GBP 20 billion ( 220 billion) over 15 years (Gov.uk, 2015). The "New Cairo Capital" city is being developed and parts of the city have already been constructed at the west side of Cairo, worth an investment of GBP 30 billion (£30 billion) (Gov.uk, 2015). Despite the growing demands of building in Egypt, the construction sector has been noted to be inefficient and underperforming. Some of the reasons of the poor performance of the construction sector are the lack of advanced procurement management techniques, absence of marketing strategy, lack of industry standards and statistics (Sakr, Sherif and El-Haggar, 2010). The

Oxford Institute for Sustainable Development, School of the Built Environment, Oxford Brookes University, Oxford, UNITED KINGDOM

*Corresponding author: fabanda@brookes.ac.uk 
construction industry in Egypt is also characterised by poor management and poor working conditions (El-Gohary and Aziz, 2014). In addition, the industry is faced with many political and economic risks, following the political disturbance and social instability including governmental changes, currency fluctuations, worker's strikes and fire risks (Khodeir and Mohamed, 2015). From an environmental perspective the performance of the industry is also wanting, with the sector responsible for $28 \%$ of the total $\mathrm{CO}_{2}$ emissions in Egypt (Sameh, 2014). The rapid rate of urbanisation and increasing pressure on what are often limited resources urges for the need to manage resources in a more sustainable manner (Reffat, 2004).

The solutions to the aforementioned challenges lie in the adoption Building Information Modelling (BIM), an emerging technology in the architectural, engineering and construction industry (AEC) (Arayici et al., 2011). The global BIM market is expected to grow form USD 1.8 billion in 2012 to USD 6.5 billion in 2020 (Machinchick and Bloom, 2012). However, similar to the majority of developing countries, the construction industry in Egypt is lagging in the adoption of new technologies aiming to improve quality of construction. This is further exacerbated by the fact that the Egyptian government does not promote the utilisation of BIM in public works and does not provide strategies, standards or vision for BIM adoption in construction projects (Elyamany, 2016).

In the light of the large number and scale of the infrastructural, residential and commercial projects in Egypt in the upcoming 15 years, there is a need to improve the performance of the construction sector. The hazardous nature of the construction industry, in addition to the high environmental impact and the rising cost of transportation and construction are the main drivers to adopt safe and sustainable construction methods and reduce the overall project lifecycle cost (Abdul-Rashid, Bassioni and Bawazeer, 2007; Ibrahim, Eldaly and Halim, 2014; Sameh, 2014). A proper adoption of BIM should enable the construction sector in Egypt to increase productivity, reduce lifecycle cost and delivery time, provide higher levels of certainty and minimise the waste and environmental impact of the construction process (Arayici et al., 2011; Azhar, 2011; Race, 2012; Abanda et al., 2015). Thus, some construction firms in Egypt and the Gulf Cooperation Council (GCC) countries are now adopting BIM in their projects partly due to market demand pressure (Gerges et al., 2017) regardless of the challenges discussed earlier. However, BIMenabled projects in the Middle Eastern countries usually follow the philosophies and techniques which are tailored to the standards and construction practices in the United Kingdom (UK). Some examples of UK standards being adopted in the Middle East including Egypt are PAS 1 192, Construction Industry Council (CIC) BIM Protocol, The Royal Institute of British Architects (RIBA) Plan of Work (PoW), etc. Given the social and economic differences between the UK and Middle Eastern countries, the difference in the practices and methodologies used in the construction sector are not necessarily the same to say the least. Bui, Merschbrock and Munkvold (2016) argued that construction firms in developing countries suffer from several limitations related to the difference in the socio-economic and technological environment between developing and developed countries. Abdel-Razek (1998) indicated that the efforts made to improve construction performance in developing countries should relate to their economic, political, social and technological environment. Thus, the endeavours to standardise the practices and methodologies should be tailored to the Egypt's social and economic aspects. This requires learning from current adoption of UK BIM standards and processes by construction firms in Egypt. The key research questions are: What are the benefits and challenges of adopting 
the RIBA PoW into practices in Egypt? How can BIM and RIBA PoW be integrated to facilitate BIM compliant project delivery? How can BIM processes and RIBA PoW be integrated to meet the needs of practices in Egypt? What can be done to foster the effective and efficient adaption and adoption of an integrated BIM-RIBA POW in the Egyptian construction industry?

The aim of this study is to investigate the integration of BIM-RIBA PoW for the delivery of construction projects in Egypt. The specific objectives are:

1. To investigate the benefits and challenges of integrating RIBA PoW into construction in Egypt.

2. To know how to integrate BIM activities into the RIBA PoW.

3. To compare the integrated BIM-RIBA PoW over traditional project lifecycle stages in Egypt.

4. To propose future research opportunities.

\section{LITERATURE REVIEW}

\section{BIM Adoption in Egypt}

BIM is a revolutionary development in the AEC industry that is believed to be able make a comprehensive improvement in the industry's current practices and methodologies by changing the way of collaboration and information distribution throughout project lifecycle (Succar, 2009; Arayici, Egbu and Coates, 2012; Abanda et al., 2015; Hardin and Mccool, 2015). At its heart, BIM is the effective management of a huge amount of information that is generated throughout the course of a construction project and added to the operational life of the asset produced (Sands, 2015). Many benefits have been attributed to BIM implementation in building design, construction and operation. Benefits include greater collaboration and enhanced communication (Race, 2012; Abanda et al., 2015), reduced lifecycle costs and project delivery time (Arayici et al., 2011; Azhar, 2011), more accurate cost estimates and automatic scheduling take-off (Race, 2012), greater visual clarity (Cousins, 2016) and increased profitability and Return on Investment (Reddy, 2012).

BIM has been adopted in many countries since the early 2000s (Jung and Lee, 2015). The Middle East and Africa are considered to be in the "beginner phase" in BIM adoption status, despite the rising rate of BIM adopted projects (Jung and Lee, 2015; Mehran, 2016; Gerges et al., 2017). The introduction of mandatory policies by governments or public organisations to promote the uptake of BIM is a key factor that have influenced the adoption of BIM in countries like the UK (Abanda and Tah, 2014; Cheng and Lu, 2015). However, the construction sector in Egypt does not have a clear understanding on the application of BIM, urging for the need to provide more knowledge and information to the sector (Elyamany, 2016). In addition, the Egyptian government does not promote the use of BIM and has no published guiding documents or standards related to the BIM field (Elyamany, 2016). Gerges et al. (2017) conducted a survey about BIM status in the Middle East, showing that only $20 \%$ of AEC companies are using BIM or are involved in the BIM implementation process. However, the same survey indicates more awareness about BIM between individuals, showing that $60 \%$ of respondents reported to have between three to 
nine years of experience and have been involved in at least two BIM projects. It is worth mentioning that the findings from BIM research in the GCC countries can be applied to Egypt and vice versa, due to the similarity in construction trends and practices (Salama et al., 2006).

\section{BIM Process Development}

A standard representation of project information throughout its lifecycle is imperative when the communication between various disciplines and specialists takes place, over long periods (Howard and Björk, 2008). In addition, adopting a standard process map of project lifecycle should facilitate the automation of engineering modelling processes and quantify information waste (Verhagen et al., 2015). Moreover, standardising project lifecycle stages should enable the automatic generation of work packages and subsequently, automate project progress measurement (Ibrahim et al., 2009). However, it has been argued that the absence of published BIM standards and guidelines, especially related to BIM process development in the Middle East is inhibiting the gaining of BIM benefits throughout project lifecycle (Mehran, 2016).

There have been several endeavours to publish a standardised BIM process throughout project lifecycle; however, each publication placed more emphases on various aspect not necessarily related to integrated BIM-RIBA PoW. While the focus of the RIBA PoW was on detailing project lifecycle stages and providing a list of activities to be carried out at each stage, the CIC BIM Protocol put more focus on the content of data drops, the level of model detail in every stage and project team roles and job descriptions (CIC, 2013). On the other hand, the British Standards Institute (BSI) in collaboration with other research institutes introduced PAS 1 192-2 and PAS1192-3, describing the management of project information throughout its lifecycle. The PAS1192-2 and PAS1192-3 introduced the utilisation of standard main documents for the information management process, such as the Employer Information Requirement (EIR), Organisation Information Requirements (OIR) and BIM Execution Plan (BEP) (BSI, 2013; 2014a; 2014b). In addition, the Digital Plan of Works (DPoW) was developed by the BIM Task Group and it is oriented around the management of information created, developed and used within BIM models, mainly related to their structure and level of development (LOD), throughout project lifecycle (BIM Task Group, 2013).

\section{The RIBA PoW}

Many standards relevant construction project life cycles exist but it has been argued that incorporating BIM paradigm into them is a huge challenge (Ahmad, Demian and Price, 2012). The RIBA introduced the RIBA PoW 2007, providing a shared framework for managing building project information during its lifecycles. The PoW was in a form of a matrix, indicating a set of key tasks to be undertaken at each stage. The project lifecycle stages were defined to be: Preparation, Design, Pre-Construction, Construction and Use. Another version was published in 2013 (as shown in Figure 1), providing more detailed project lifecycle stages and more flexibility to include multiple procurement routes instead of the selected traditional procurement route in the 2007 version (RIBA, 2013). However, the 2013 version has 
been criticised for being too architect-focused and for condensing construction into a single stage (Designing Buildings Ltd., 2017). Both 2007 and 2013 versions did not relate to BIM in any of the mentioned roles, tasks or deliverables.

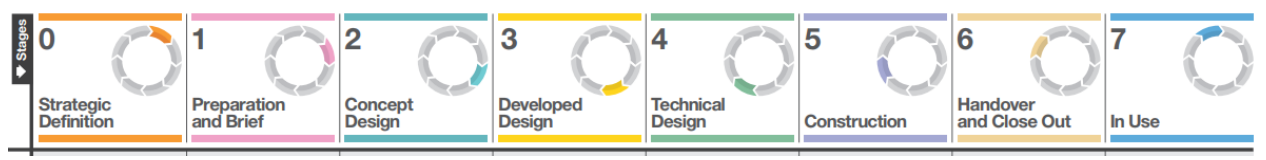

Figure 1. Project lifecycle stages in RIBA PoW 2013

Source: RIBA (2013)

BIM Overlay to the RIBA PoW was introduced in 2012 based on the 2007 version of the RIBA PoW (Sinclair, 2012). The BIM Overlay introduced core BIM activities to be carried out in each project lifecycle stage. The BIM activities focused on sustainability aspects. Indeed, the Overlay is about how BIM can be used in delivering sustainability aspects of a construction projects. At the end of each stage, information exchange should take place between stakeholders in what is called a Data Drop. The BIM Overlay followed the Green Overlay (Gething, 2011), which was focused on sustainability key tasks and objectives throughout project lifecycle. However, the objectives identified in the BIM Overlay are too general and does not indicate standard content of Data Drops and does not identify submission protocols or quality gates between stages, in addition to the focus on sustainability activities. Moreover, the table structure of the RIBA PoW does not enable the modelling of the information flow between project main participants throughout project lifecycle.

\section{Construction Project Lifecycle in Egypt}

Perhaps, partly due to the fact that the Egyptian government does not promote the use of BIM in the construction sector (Elyamany, 2016), there is a lack of publications and guidance on the subject of developing a standard BIM process. Hence, a document has been obtained from a real BIM implementation project in Dar Al-Mimar Group (DMG) Company, illustrating information flow between project stakeholders throughout traditional project lifecycle stages. DMG is a group of companies, specialised in the development, design, construction and operation of luxury real estate apartments and is located in Cairo, Egypt (DMG, 2011). The document obtained, was an assessment of the "as-is" condition of the group, as a first step in their BIM implementation. The BIM implementation was managed by Virtual Projects, a BIM consultant located in Cairo, Egypt (Virtual Projects, 2015). Figure 2 shows a simplified version of the project lifecycle obtained from DMG.

While the process map structure is more advantageous over the table structure of the RIBA PoW in showing the interdependencies between project stakeholders, there is no description of the activities to be carried out in each stage. In addition, the project lifecycle in Egypt does not promote Integrated Project Delivery, as there is no indication of early involvement of the contractor or the facility manager before the Preconstruction stage. Worth to mention that the project lifecycle process map shown in Figure 2 is not an agreed country standard in Egypt, but rather was developed by the participation of AEC companies under DMG. 


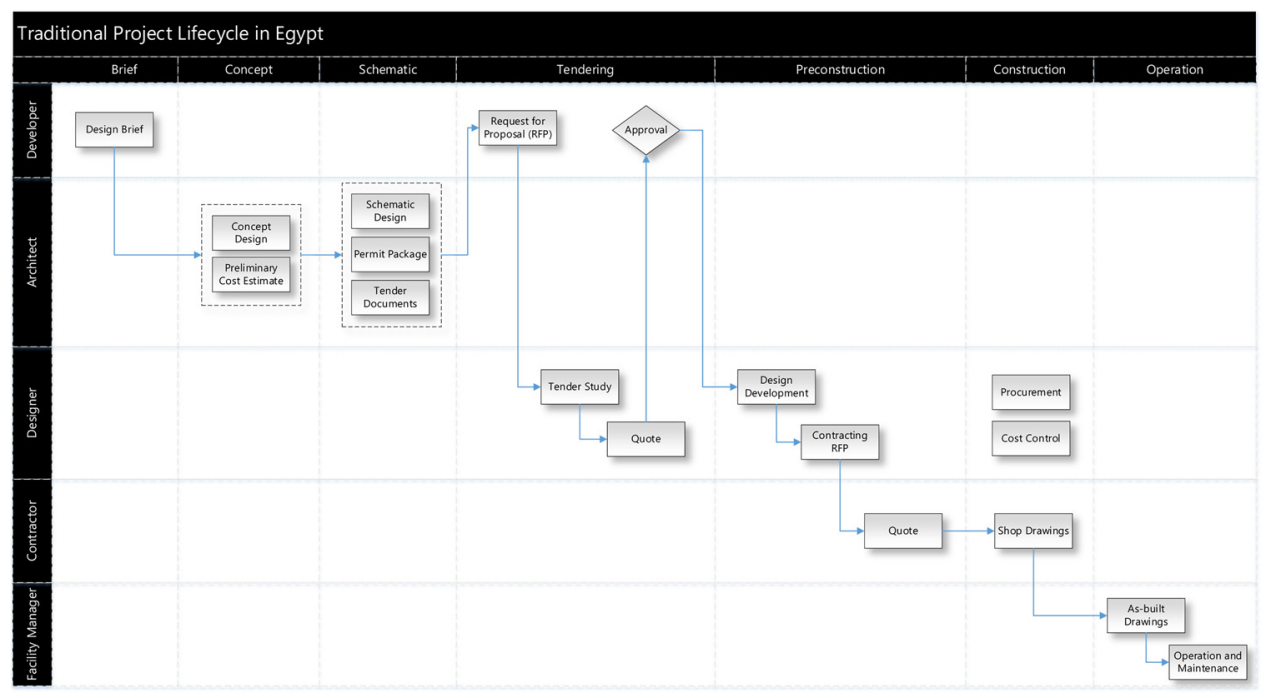

Figure 2. Traditional Project Lifecycle in Egypt

In surmise, a number of issues can be deduced from the review in the preceding sections. Firstly, while standard project life cycle is well established in the developed countries, e.g. RIBA PoW, it is not common in Egypt. The sketchy lifecycle framework proposed by DMG in Figure 2 is not standardised. Secondly, efforts are already being made in the UK to incorporate BIM into the standard project life cycle (i.e., Sinclair [2012]), an aspect yet take off in Egypt. Thirdly, in an effort to improve efficiency, Middle East countries including Egypt are increasingly adopting UK BIM and project life cycle standards. However, their experiences have not been captured in peer-reviewed literature. Thus, the need to investigate the issues related to the adoption of UK BIM and project life cycles by Egyptian construction companies. To achieve this aim, an appropriate methodology will be pursued.

\section{RESEARCH METHODOLOGY}

\section{Data Collection Methods}

In this section the research methods used and their justification will be discussed. Table 1 shows the selected research methods, mapped against corresponding research objectives and the expected outcomes.

\section{Data Analysis Methods}

Grounded theory has been selected as the data analysis approach. Analysing qualitative data comprises five main stages: Preparation, Summarising (Coding), Categorisation, Structuring and Interpretation (Saunders, Lewis and Thornhill, 2009; Creswell, 2014). Table 2 shows a description of qualitative data analysis stages. 
Table 1. Research methods and the expected outcome for each research objective

\begin{tabular}{cll}
\hline Objective & Methods & Outcomes \\
\hline A & Focus Group & $\begin{array}{l}\text { A list of benefits and challenges of integrating RIBA } \\
\text { PoW in Egypt. }\end{array}$ \\
B & $\begin{array}{l}\text { Literature Review + } \\
\text { Focus Group }\end{array}$ & $\begin{array}{l}\text { A list of BIM objectives, activities and deliverables at } \\
\text { each stage of the project lifecycle in the RIBA PoW. }\end{array}$ \\
C & $\begin{array}{l}\text { Literature Review + } \\
\text { Focus Group }\end{array}$ & $\begin{array}{l}\text { Integrated BIM-RIBA PoW based on Egyptian } \\
\text { construction industry practices. }\end{array}$ \\
& Personal Discussion + & $\begin{array}{l}\text { A list of points that require further research and } \\
\text { investigation. }\end{array}$ \\
\hline
\end{tabular}

Table 2. Description of the Stages of Qualitative Data Analysis Process Used in this Research

\begin{tabular}{|c|c|}
\hline Stage & Description \\
\hline Preparation & $\begin{array}{l}\text { A transcript is produced from recorded audio material, of each focus } \\
\text { group. }\end{array}$ \\
\hline Coding & $\begin{array}{l}\text { Transcript data are organised, by labelling specific segments with } \\
\text { descriptive meanings, in a process known by "The Coding Process". } \\
\text { The labelled segments mark interesting features of the data, related } \\
\text { to the research objective. Codes were generated based on emerging } \\
\text { information collected from participants, during the analysis of } \\
\text { transcripts. This method was selected because it is more suitable for } \\
\text { social science research than using a codebook with predetermined } \\
\text { codes (Creswell, 2014). }\end{array}$ \\
\hline Categorisation & $\begin{array}{l}\text { Common themes/categories are generated through recognising the } \\
\text { relationships between summarised data. These categories represent } \\
\text { the major findings of the research (Creswell, 2014). }\end{array}$ \\
\hline Structuring & $\begin{array}{l}\text { A structure of common themes and sub-themes is made, supported by } \\
\text { quotes from the transcript. }\end{array}$ \\
\hline Interpretation & $\begin{array}{l}\text { Interpretations are made of research findings, i.e. lessons learnt from the } \\
\text { research. The output of this stage is mainly based on the researcher's } \\
\text { personal interpretation of the research findings. }\end{array}$ \\
\hline
\end{tabular}

\section{Sampling Technique}

Achieving research objectives requires certain characteristics of the research sample, e.g. background, BIM experience, specialisation... etc. The criteria for selecting participants for the focus groups were the availability of BIM experience, in addition to the involvement in different project lifecycle stages. Fifteen participants were selected with disparate background (Architecture, Building Services, Structural... etc.) and backgrounds (Design, Construction, Project Management... etc.). However, it was not possible finding participants with facilities management background who have been involved in construction projects using BIM. 


\section{Justification of Selected Research Methods}

The core of this study is about the issues associated with the adoption of UK RIBA PoW and BIM standards in Egypt. Obtaining any data or information related to such issues can be informed by the experiences and perspectives of industry practitioners. Hence, the qualitative research method is very suitable to this type of research (Onwuegbuzie, 2003; Kothari, 2004; Saunders, Lewis and Thornhill, 2009; Creswell, 2014). The adopted data collection technique is the focus group technique, as it will enable the investigator to interview a larger number of respondents, in addition to exploring a breadth of points of view from participants. In addition, the focus group will stimulate the debates and conflicts between different specialities throughout project lifecycle, as the opinion of one participant will be validated by other participants (Krueger, 1997; Freitas et al., 1998; Naoum, 2007; Onwuegbuzie et al., 2009).

The location for conducting focus groups has been selected to be easy to find by participants, free from noise distraction and equipped with the required furniture and audio facilities (Freitas et al., 1998). Audio-recording has been selected to record the interview data, as it enables the interviewer to concentrate on questioning and listening, in addition to enabling the re-listening of the interview for more in-depth analysis (Saunders, Lewis and Thornhill, 2009). The main equipment used during the focus group interviews are projector/40" television (TV) + personal computer (PC), which used to present the RIBA PoW and the traditional project lifecycle stage in Egypt, and audio-recording software which used to audio-record the focus group discussion in an acceptable quality.

\section{DATA COLLECTION AND ANALYSIS}

\section{Overview of Participants}

The BIM experience of participants ranges from three years to seven years, while their field experience ranges from three years to 10 years. All participants have been involved in at least two building projects using BIM. The background of all participants is mainly related to the design and construction stages. The inclusion of different backgrounds and experiences should stimulate a comprehensive discussion about main activities in the PoW. In addition, the variety in participants' backgrounds should minimise the bias of a certain opinion towards a specific trade or stakeholder. Figure 3 shows a summary of participants' experiences and backgrounds.

Table 3 shows a summary of backgrounds of participants in Focus Group I. The BIM experience of Focus Group I participants ranges from five to seven years, while the field experience ranges from seven to 10 years. The experience of participants is mainly related to the design and constructions stages.

Table 4 shows a summary of backgrounds of participants in Focus Group II. The BIM experience ranges from three to five years, while the field experience ranges from two to five years. All participants have been involved in the design and construction stages. 


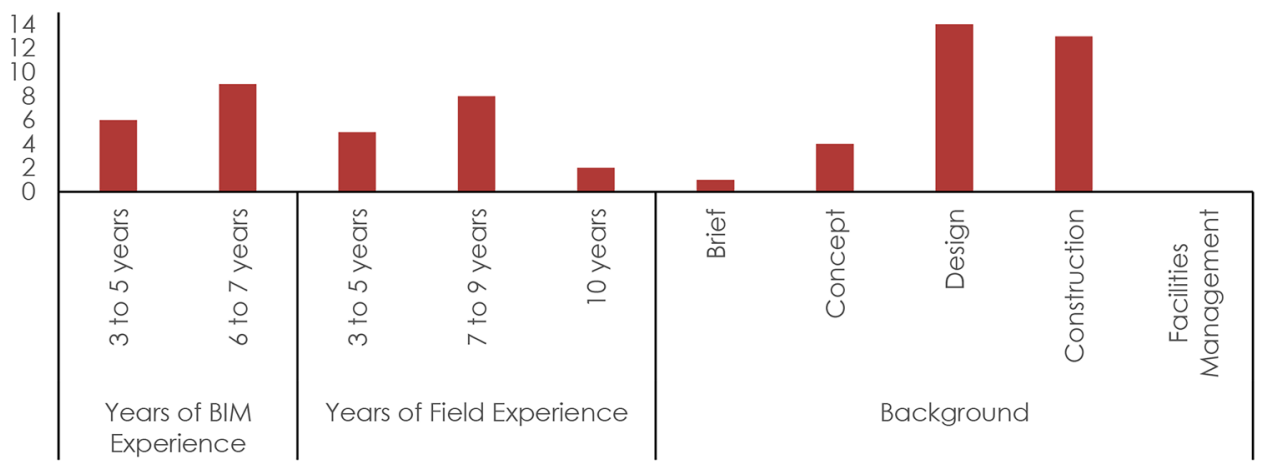

Figure 3. Summary of the Experience and Background of Focus Group Participants

Table 3. Focus Group I Participants Overview

\begin{tabular}{llll}
\hline Name & Title & Background & Experience \\
\hline Participant A & BIM Manager & $\begin{array}{l}\text { Design; } \\
\text { Construction }\end{array}$ & $\begin{array}{l}\text { Six years BIM experience; } \\
10 \text { years field experience }\end{array}$ \\
Participant B & $\begin{array}{l}\text { Architectural/Structural } \\
\text { BIM Coordinator }\end{array}$ & $\begin{array}{l}\text { Design; } \\
\text { Construction }\end{array}$ & $\begin{array}{l}\text { Five years BIM experience; } \\
\text { Seven years field experience }\end{array}$ \\
Participant C & $\begin{array}{l}\text { Mechanical BIM } \\
\text { Team Leader }\end{array}$ & $\begin{array}{l}\text { Design; } \\
\text { Construction }\end{array}$ & $\begin{array}{l}\text { Six years BIM experience; } \\
\text { Seven years field experience }\end{array}$ \\
Participant D & Electrical BIM & Design; & Seven years BIM experience; \\
& Team Leader & Construction & Nine years field experience \\
Participant E & MEP BIM Coordinator & Design; & Six years BIM experience; \\
(Participant E) & & Construction & Seven years field experience \\
\hline
\end{tabular}

Table 4. Focus Group II Participants Overview

\begin{tabular}{llll}
\hline Name & Discipline & Background & Experience \\
\hline Participant A & $\begin{array}{l}\text { Architectural BIM } \\
\text { Team Leader }\end{array}$ & $\begin{array}{l}\text { Brief; Concept; } \\
\text { Design; } \\
\text { Construction }\end{array}$ & $\begin{array}{l}\text { Three years BIM experience; } \\
12 \text { years field experience }\end{array}$ \\
Participant B & BIM Consultant & $\begin{array}{l}\text { Design; } \\
\text { Construction }\end{array}$ & $\begin{array}{l}\text { Seven years BIM experience; } \\
\text { Seven years field experience }\end{array}$ \\
Participant C & $\begin{array}{l}\text { Architectural/ } \\
\text { Structural BIM } \\
\text { Coordinator }\end{array}$ & $\begin{array}{l}\text { Concept; Design; } \\
\text { Construction }\end{array}$ & $\begin{array}{l}\text { Six years BIM experience; } \\
\text { Seven years field experience }\end{array}$ \\
Participant D & $\begin{array}{l}\text { Architectural Senior } \\
\text { BIM Engineer }\end{array}$ & $\begin{array}{l}\text { Design; } \\
\text { Construction }\end{array}$ & $\begin{array}{l}\text { Six years BIM experience; } \\
\text { Nine years field experience }\end{array}$ \\
Participant E & MEP BIM Coordinator & $\begin{array}{l}\text { Design; } \\
\text { Construction }\end{array}$ & Four years BIM experience; \\
(Participant E) & Seven years field experience \\
\hline
\end{tabular}


Table 5 shows a summary of backgrounds of participants in Focus Group III. The BIM experience ranges from three to five years. The participants of Focus Group III were selected to explore the thoughts and experiences at the operational level, as Focus Group I and II have represented the strategic and organisational level to some extent.

Table 5. Focus Group III Participants Overview

\begin{tabular}{|c|c|c|c|}
\hline Name & Discipline & $\begin{array}{l}\text { Background } \\
\text { (Lifecycle Stages) }\end{array}$ & Experience \\
\hline Participant A & $\begin{array}{l}\text { Mechanical BIM } \\
\text { Engineer }\end{array}$ & Design; Construction & $\begin{array}{l}\text { Three years BIM experience; } \\
\text { Three years field experience }\end{array}$ \\
\hline Participant B & $\begin{array}{l}\text { Mechanical BIM } \\
\text { Engineer }\end{array}$ & Design; Construction & $\begin{array}{l}\text { Three years BIM experience; } \\
\text { Three years field experience }\end{array}$ \\
\hline Participant C & $\begin{array}{l}\text { Mechanical BIM } \\
\text { Engineer }\end{array}$ & $\begin{array}{l}\text { Design (developed + } \\
\text { technical) }\end{array}$ & $\begin{array}{l}\text { Four years field experience; } \\
\text { Four years field experience }\end{array}$ \\
\hline Participant D & $\begin{array}{l}\text { Electrical BIM } \\
\text { Engineer }\end{array}$ & $\begin{array}{l}\text { Design (developed + } \\
\text { technical) }\end{array}$ & $\begin{array}{l}\text { Two years BIM experience; } \\
\text { Three years field experience }\end{array}$ \\
\hline Participant E & $\begin{array}{l}\text { Electrical BIM } \\
\text { Reviewer }\end{array}$ & Design; Construction & $\begin{array}{l}\text { Five years BIM experience; } \\
\text { Five years field experience }\end{array}$ \\
\hline
\end{tabular}

\section{Flow of Discussion and Moderator Involvement}

The level of involvement of the interviewer kept moving from high to low, to high again, according to the dynamics of discussion. Each focus group started with high level of involvement of the interviewer, by giving an introduction to illustrate what is RIBA PoW and why this research is conducted. The first question was then asked, leading to an unstructured discussion about the potential answers to the asked question. During discussion, the interviewer level of involvement was low and then moved to high by concluding the discussion and moving to the next question. The main involvement of the interviewer in discussion was to clarify any misunderstanding or issues. In some cases, the interviewer had to suggest some ideas from a previous focus group to a current group. This helped to stimulate participants' thinking into finding relevant answers and validates different opinions against each other. A summary of the focus groups settings is presented in Table 6.

Table 6. A Summary of Conducted Focus Groups Settings

\begin{tabular}{llllll}
\hline Focus Group & Location & Date and Time & $\begin{array}{l}\text { Setting of } \\
\text { Interview }\end{array}$ & $\begin{array}{l}\text { Recording } \\
\text { Method }\end{array}$ & Duration \\
\hline Focus Group I & $\begin{array}{l}\text { Virtual } \\
\text { Projects }\end{array}$ & $\begin{array}{l}28 \text { th August } \\
2017\end{array}$ & $\begin{array}{l}\text { Meeting } \\
\text { room }\end{array}$ & $\begin{array}{l}\text { Audio } \\
\text { recording }\end{array}$ & 65 min \\
Focus Group II & $\begin{array}{l}\text { Virtual } \\
\text { Projects }\end{array}$ & $\begin{array}{l}30 \text { th August } \\
2017\end{array}$ & $\begin{array}{l}\text { Meeting } \\
\text { room }\end{array}$ & $\begin{array}{l}\text { Audio } \\
\text { recording }\end{array}$ & 62 min \\
Focus Group III & $\begin{array}{l}\text { Kemet } \\
\text { Corporation }\end{array}$ & $\begin{array}{l}5 \text { th September } \\
2017\end{array}$ & $\begin{array}{l}\text { Meeting } \\
\text { room }\end{array}$ & $\begin{array}{l}\text { Audio } \\
\text { recording }\end{array}$ & 78 min \\
& Coom & & & \\
\hline
\end{tabular}




\section{DATA ANALYSIS AND INTERPRETATION}

This section illustrates the findings of research based on the qualitative analysis of focus groups' transcript.

\section{Objective A: The Benefits and Challenges of Integrating the RIBA PoW into Construction in Egypt}

The aim was to explore the potential gains of integrating the RIBA PoW in construction practices and Egypt and the possible difficulties of such integration. Three main themes have been identified.

Table 7 shows the identified common themes through the thematic analysis conducted on Focus Groups' discussion.

Table 7. Qualitative Analysis Matrix: Research Question 1

\begin{tabular}{|c|c|c|c|}
\hline \multirow{2}{*}{ Issue } & \multicolumn{3}{|c|}{ Evidence } \\
\hline & Focus Group I & Focus Group II & Focus Group III \\
\hline $\begin{array}{l}\text { RIBA PoW is not } \\
\text { beneficial in its } \\
\text { default form for } \\
\text { construction in } \\
\text { Egypt }\end{array}$ & $\begin{array}{l}\text { "What is the difference } \\
\text { between the RIBA PoW and } \\
\text { any other general process } \\
\text { for managing project } \\
\text { lifecycle?" - Participant A } \\
\text { "Each stage should be } \\
\text { further detailed as the } \\
\text { current is too generic." } \\
\text { - Participant E }\end{array}$ & $\begin{array}{l}\text { "Generally speaking, these } \\
\text { project lifecycle stages } \\
\text { are already implemented } \\
\text { in Egypt." - Participant A } \\
\text { "I believe these stages are } \\
\text { already there. RIBA is not } \\
\text { offering something new." } \\
\text { - Participant D }\end{array}$ & $\begin{array}{l}\text { "I think if you ask any } \\
\text { developer in Egypt, what } \\
\text { will you do to deliver the } \\
\text { project? The developer } \\
\text { will mention the RIBA } \\
\text { PoW stages, but with } \\
\text { different terms, as they } \\
\text { are the logic sequence } \\
\text { of each construction } \\
\text { project." - Participant A }\end{array}$ \\
\hline $\begin{array}{l}\text { More detailing } \\
\text { and guidance } \\
\text { is required }\end{array}$ & $\begin{array}{l}\text { "It is required to develop } \\
\text { detailed workflows inside } \\
\text { each stage of the project } \\
\text { lifecycle." - Participant E } \\
\text { "As a development of } \\
\text { the current process, the } \\
\text { RIBA PoW does not really } \\
\text { offer much, as there are } \\
\text { neither detailed workflows } \\
\text { nor guidelines on how to } \\
\text { achieve the high-level } \\
\text { objectives." - Participant A } \\
\text { "Enforcing a properly } \\
\text { detailed PoW should } \\
\text { organise the process to a } \\
\text { great extent." - Participant A }\end{array}$ & $\begin{array}{l}\text { "The idea is how to } \\
\text { execute each stage, } \\
\text { either with BIM or } \\
\text { traditional." - Participant A }\end{array}$ & $\begin{array}{l}\text { "There are still many } \\
\text { operational problems } \\
\text { that need to be } \\
\text { addressed, what is the } \\
\text { best layout for tower } \\
\text { cranes? Which trade } \\
\text { should be installed first... } \\
\text { etc." - Participant B }\end{array}$ \\
\hline $\begin{array}{l}\text { Benefits of } \\
\text { integrating } \\
\text { RIBA PoW into } \\
\text { construction } \\
\text { industry in } \\
\text { Egypt }\end{array}$ & $\begin{array}{l}\text { "Making entities on the same } \\
\text { page." - Participant D }\end{array}$ & & $\begin{array}{l}\text { "Any attempt to } \\
\text { standardise practices } \\
\text { should be of value in } \\
\text { Egypt, due to the lack of } \\
\text { published material." } \\
\text { - Participant A }\end{array}$ \\
\hline
\end{tabular}


Table 7. (continued)

\begin{tabular}{|c|c|c|c|}
\hline \multirow{2}{*}{ Issue } & \multicolumn{3}{|c|}{ Evidence } \\
\hline & Focus Group I & Focus Group II & Focus Group III \\
\hline $\begin{array}{l}\text { People's } \\
\text { resistance to } \\
\text { change is a } \\
\text { main challenge } \\
\text { in integrating } \\
\text { RIBA PoW in } \\
\text { Egypt }\end{array}$ & $\begin{array}{l}\text { "The main challenge is the } \\
\text { resistance to change and } \\
\text { the lack of awareness that } \\
\text { integrating a standard PoW } \\
\text { will make things easier." } \\
\text { - Participant C; Participant E }\end{array}$ & $\begin{array}{l}\text { "People usually refrain } \\
\text { from taking responsibility } \\
\text { of what they have built } \\
\text { on-site, because they } \\
\text { shared the building } \\
\text { process with many } \\
\text { different parties." } \\
\text { - Participant C }\end{array}$ & $\begin{array}{l}\text { "The challenges we } \\
\text { may face implementing } \\
\text { a standard PoW, is } \\
\text { people's resistance to } \\
\text { change." - Participant C }\end{array}$ \\
\hline $\begin{array}{l}\text { Other } \\
\text { challenges of } \\
\text { integrating RIBA } \\
\text { PoW in Egypt }\end{array}$ & $\begin{array}{l}\text { "Another challenge is } \\
\text { that each company will } \\
\text { understand the PoW in a } \\
\text { different way." } \\
\text { - Participant A }\end{array}$ & $\begin{array}{l}\text { "The handover stage. } \\
\text { There is no distinct } \\
\text { stage for the handover } \\
\text { processes." - Participant A } \\
\text { "This is against the } \\
\text { culture here anyways. } \\
\text { The handover process } \\
\text { implicitly means that } \\
\text { you give a guarantee of } \\
\text { what you have built on- } \\
\text { site, which doesn't really } \\
\text { happen." - Participant A }\end{array}$ & \\
\hline
\end{tabular}

Three main patterns of information identified from the responses of participants are as follows.

\section{Whether the RIBA PoW is beneficial to the Egyptian construction sector in its default form}

Participants of Focus Group I and Focus Group II agreed that the RIBA PoW does not offer much value in its default form. It was criticised for being too general and lacking real guidance on what needs to be done in each stage. The defined project lifecycle stages are already implemented, but with different terms. In other words, people follow these stages by default, since they are the logical sequence of a building project. For more effective benefits, the PoW should be used to illustrate how to achieve the objectives of each lifecycle stage, instead of just providing an indication of what needs to be done. Participants of Focus Group III did not explicitly provide the same statement. The benefits they have identified were related to the benefits of standardisation of process in general, not the benefits of the RIBA PoW in particular. In addition, the identified benefits were driven by the fact that there is no published material related to project lifecycle management in Egypt. Therefore, any attempt to standardise the process would be of benefit. Integrating a standard PoW into construction sector in Egypt should provide a better management of the initiation of each stage by aligning all project stakeholders to the same terms, tasks and overall plan. This should help minimise conflicts between project stakeholders throughout its lifecycle. In addition, it is a good start to unify organisational and operational practices and standards, as they are a reason of much rework, because currently they are subject to the different opinions of individuals. This can be interpreted as a consensus agreement that the RIBA PoW is not beneficial for 
the construction sector in Egypt in its default form, but it can be if it is more detailed and more related to BIM. Participants from all focus groups suggested that the RIBA PoW should provide more guidance and details on necessary BIM activities in each stage. There was an emphasis on the importance of developing detailed workflows and plans of work on both the organisational and operational levels. This places more credibility on the significance of research objectives of integrating BIM activities into the RIBA PoW and that any developed PoW should be integrated with detailed description of BIM activities.

\section{People's resistance to change is a main challenge}

There has been a consensus agreement among all focus groups that the main challenge facing the integration of the RIBA PoW is the people's resistance to change. The resistance to change is mainly due to lack of awareness and sticking to old methodologies. Suggestions have been made to overcome resistance to change through mandating policies and education/training activities. For an effective integration of the RIBA PoW in Egypt, it must be published by an authoritative body, who will take the responsibility of encouraging and enforcing in some cases - construction companies to adopt the published standards. People will usually try to avoid any additional constraints, even if these constraints were to their benefit. This can be solved by educating people about the benefits of such changes and rewarding those who adopt the change.

\section{The difficulty of the explicit implication of the handover stage}

The challenges of integrating the RIBA PoW in Egypt are mainly related to the handover stage. The handover is not considered as a stage in Egypt, but rather it is a concurrent activity with the construction stage. The handover stage is generally against the nature of projects in Egypt. A handover implicitly means taking the responsibility of what has been built in the construction site. The handover process is usually divided into many stages over a long period of time, which distributes the responsibility of constructed objects over many entities, which makes it difficult to account a single entity for discovered construction flaws. Hence, people usually refrain from taking responsibility of what was built on site, making it difficult to impose a distinct handover stage. Despite this is the case in most governmental projects, it is not applied to certain building types such as hospitals.

\section{Objective B: The Integration of BIM Activities into the RIBA PoW}

Objective B aimed to explore how to develop a BIM-RIBA PoW. Data were collected to achieve objective B using two questions. First question is related to identifying strategic BIM objectives, based on the difficulties of each stage using traditional methods. The second question is related to identifying main BIM deliverables at each lifecycle stage and describing model progression using level of detail (LOD). This section illustrates common patterns that occurred during the discussion while the information on the identified BIM objectives, activities, deliverables and the developed BIM-RIBA PoW is included in the next section.

Table 8 and Table 9 show the identified common themes through the thematic analysis conducted on Focus Groups' discussion. 


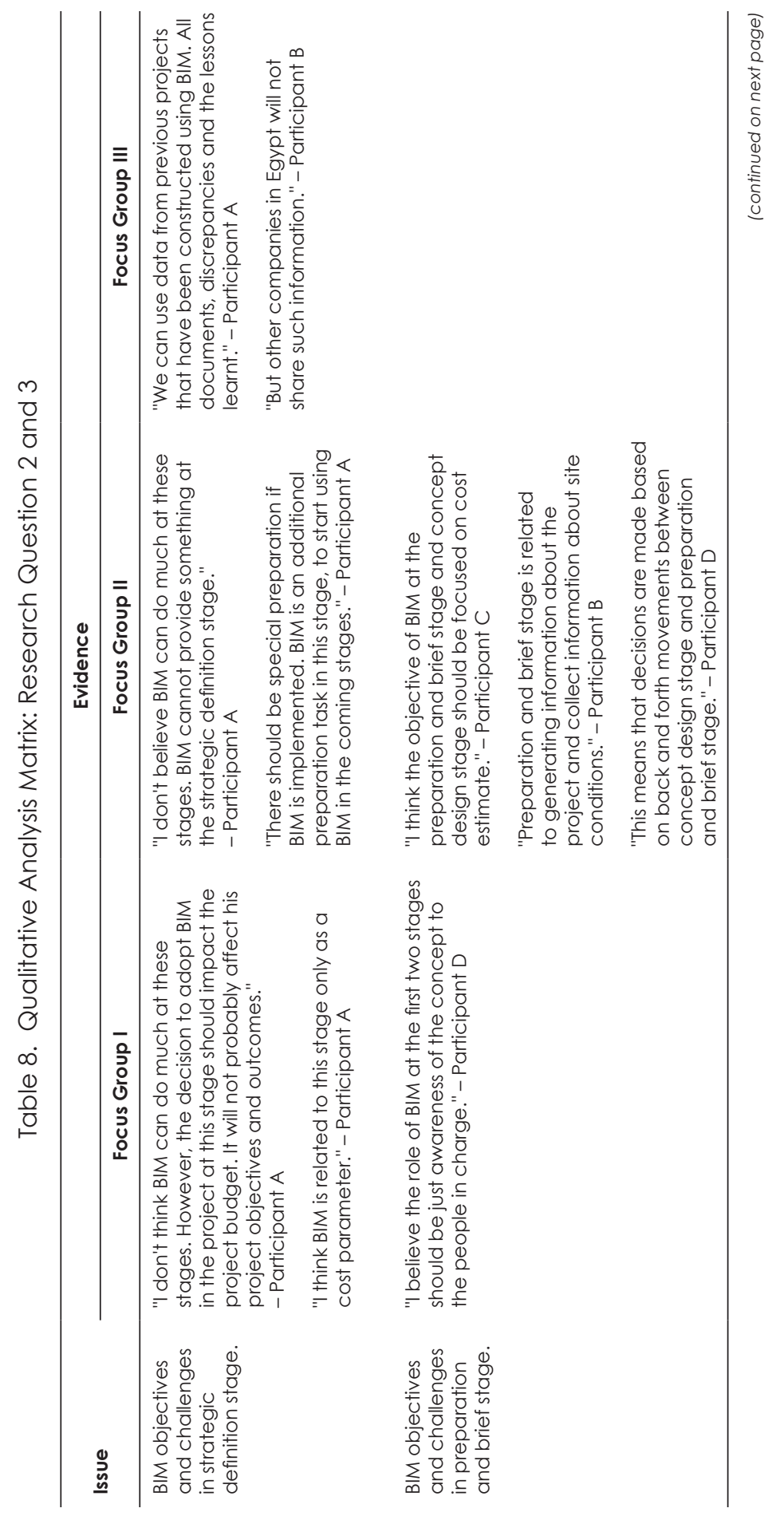




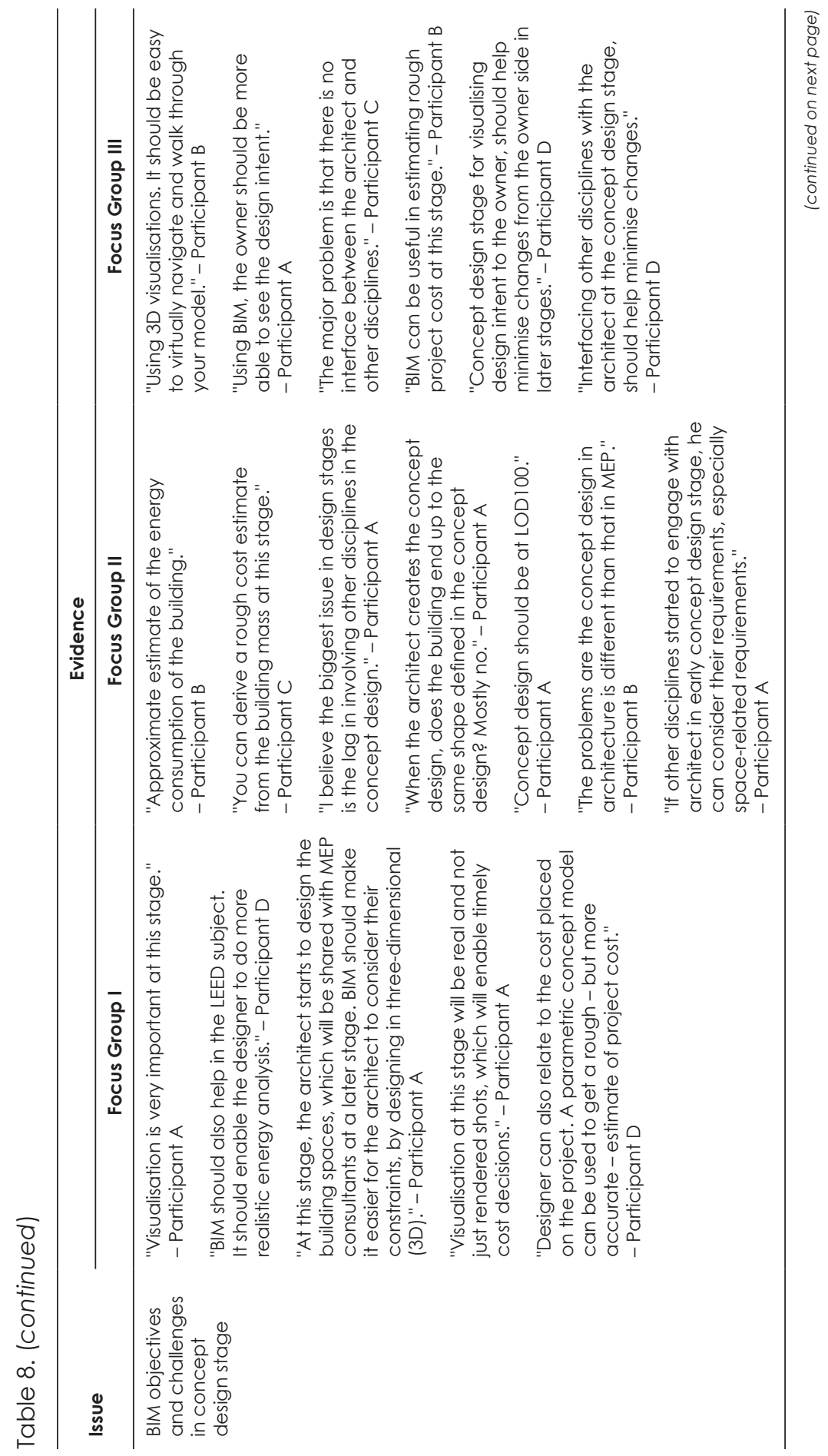




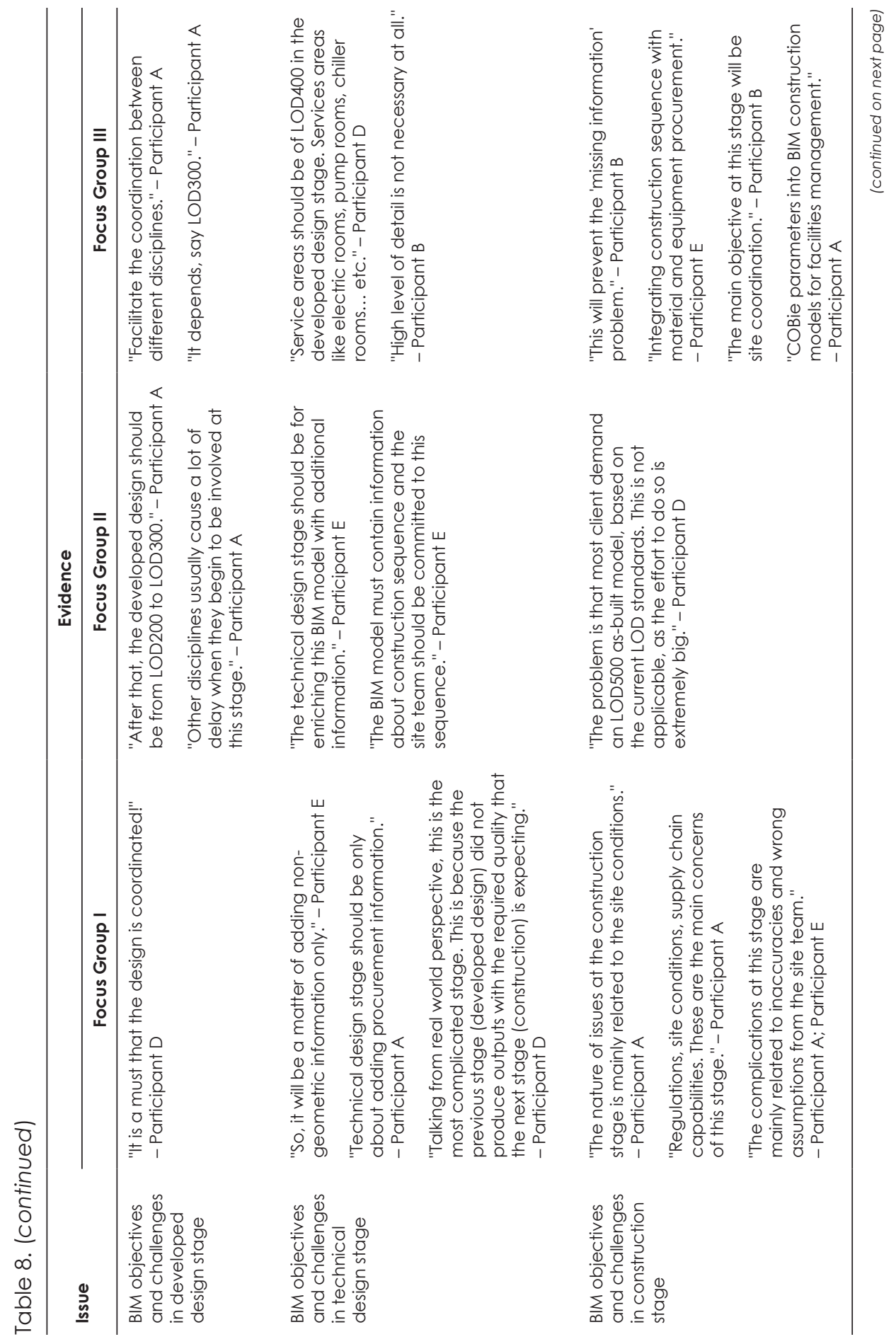




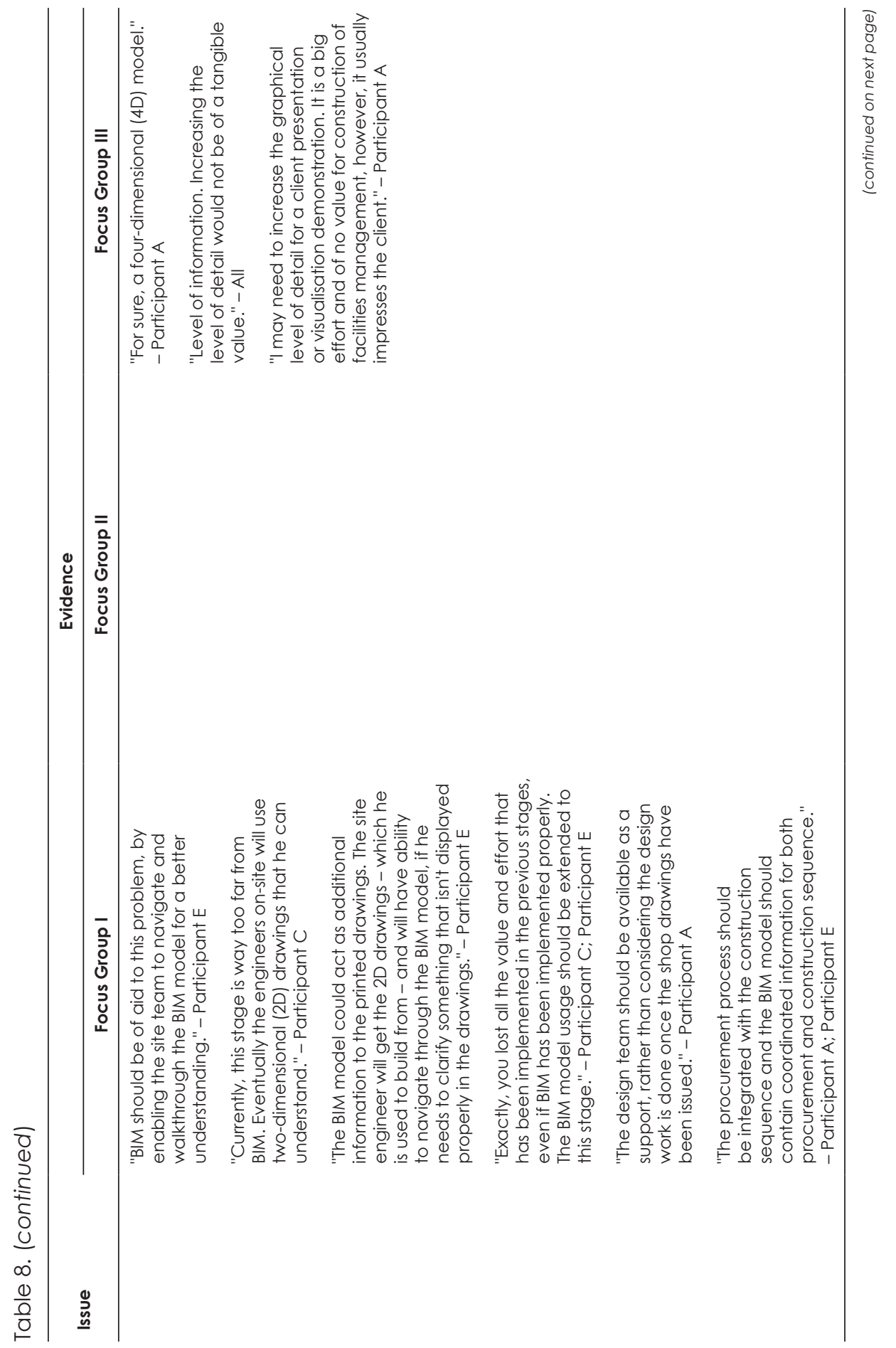




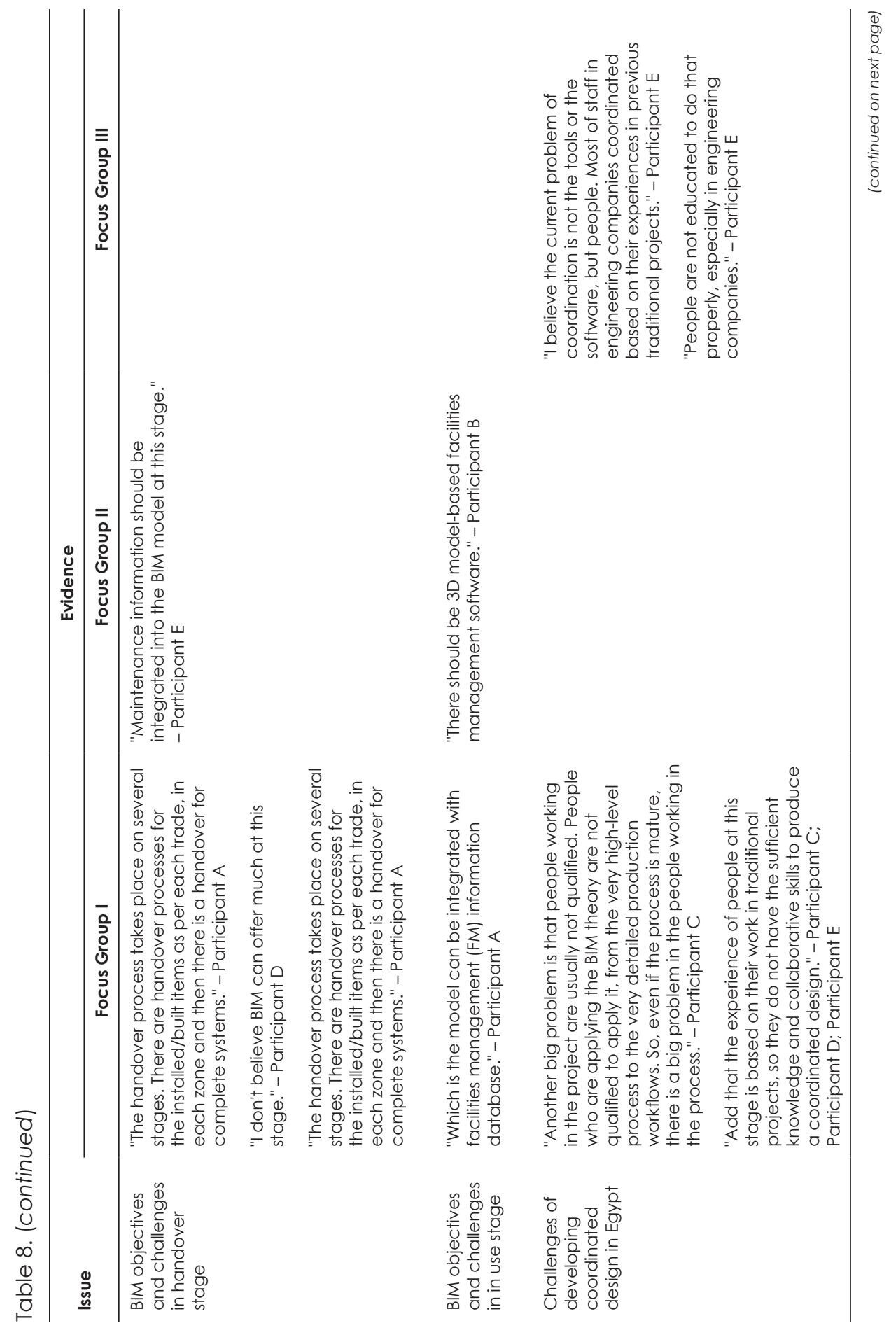



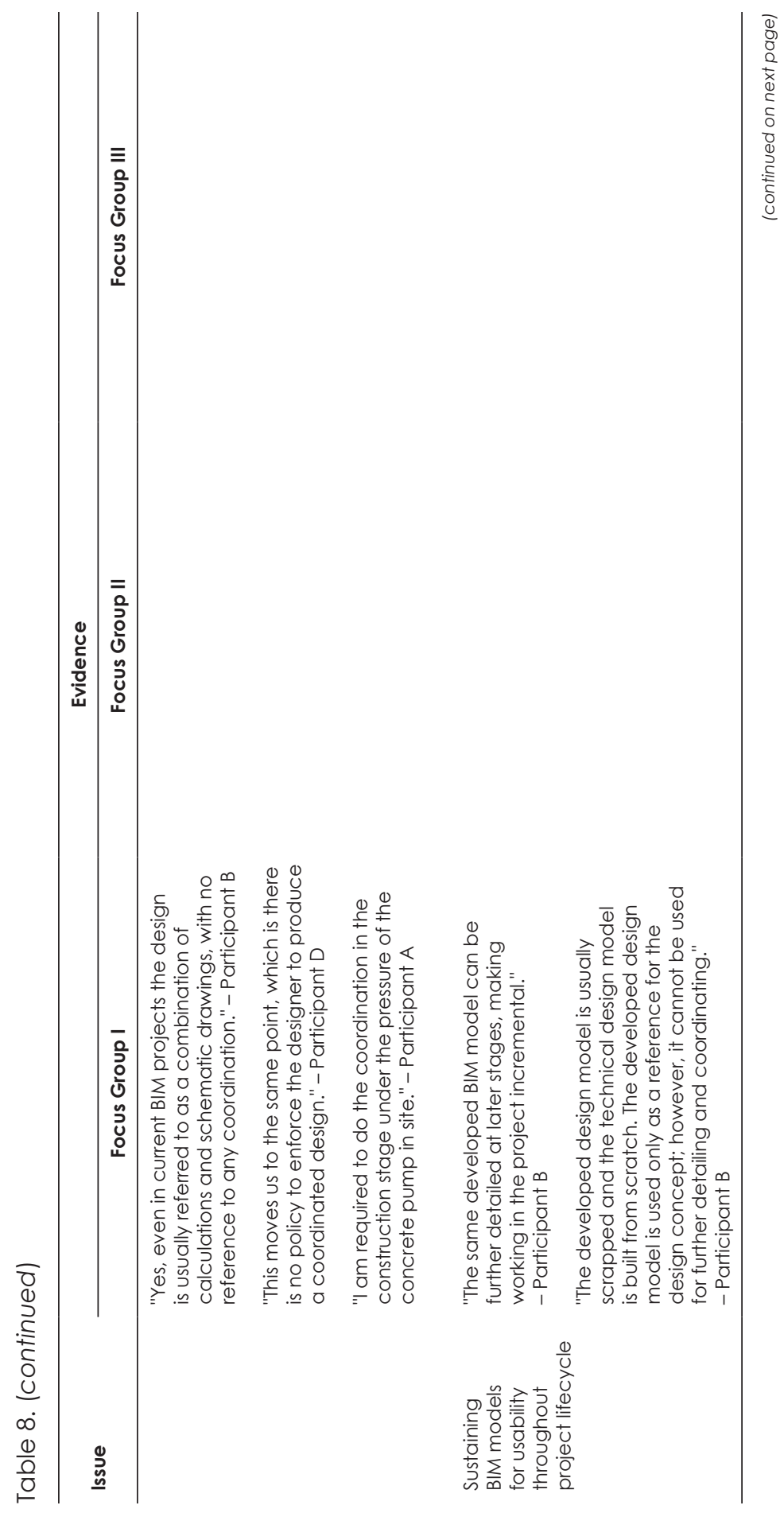


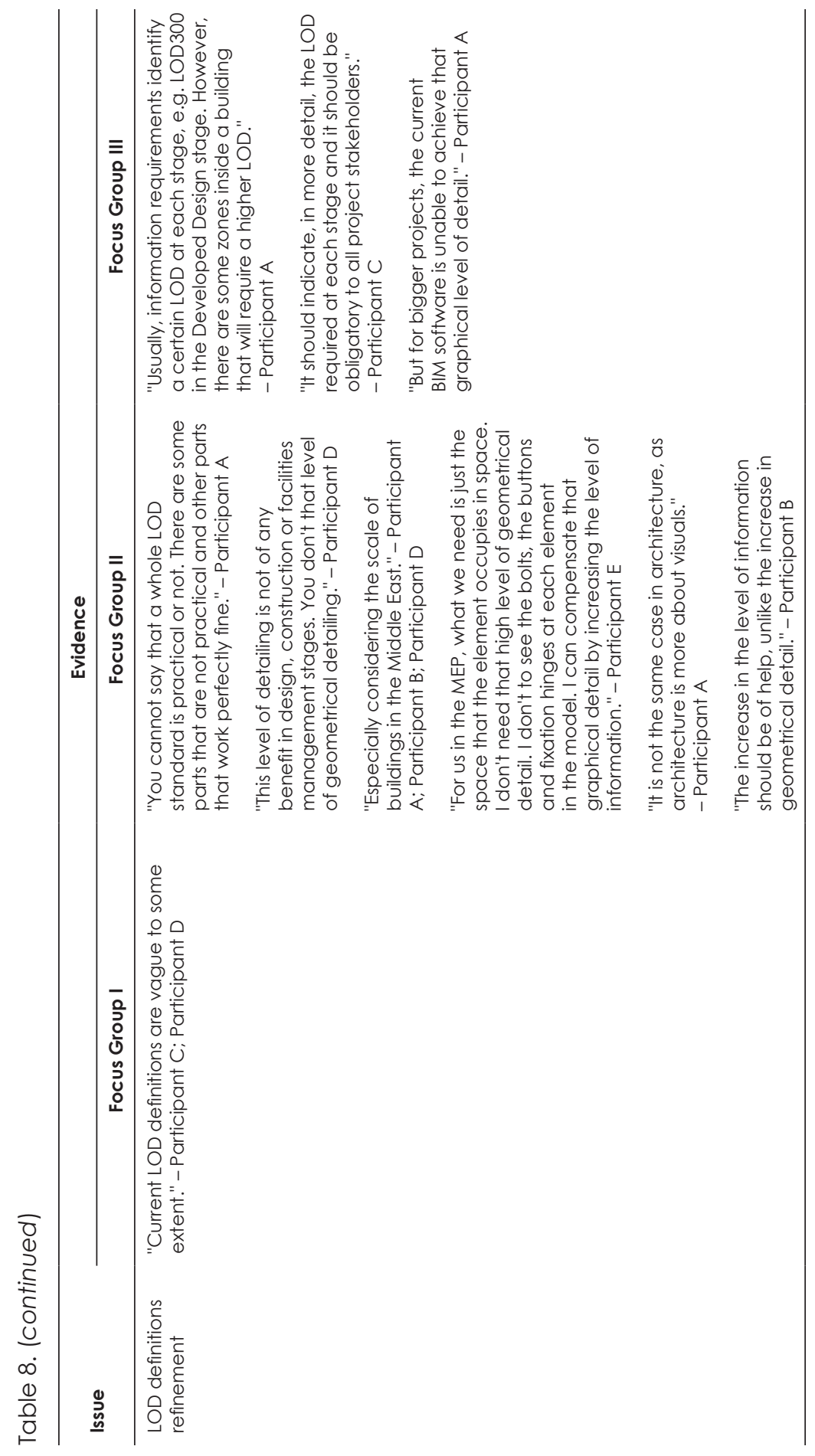




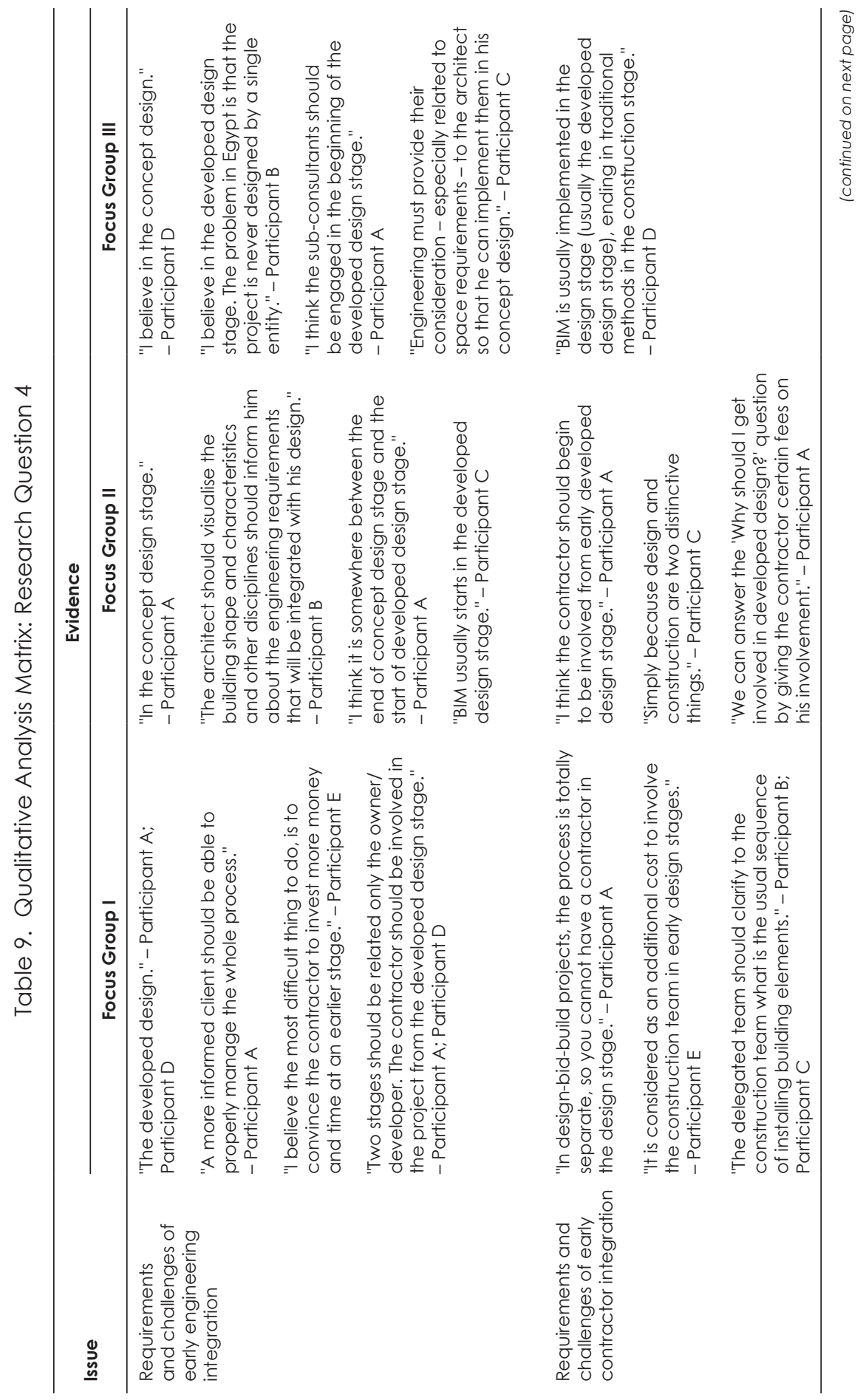




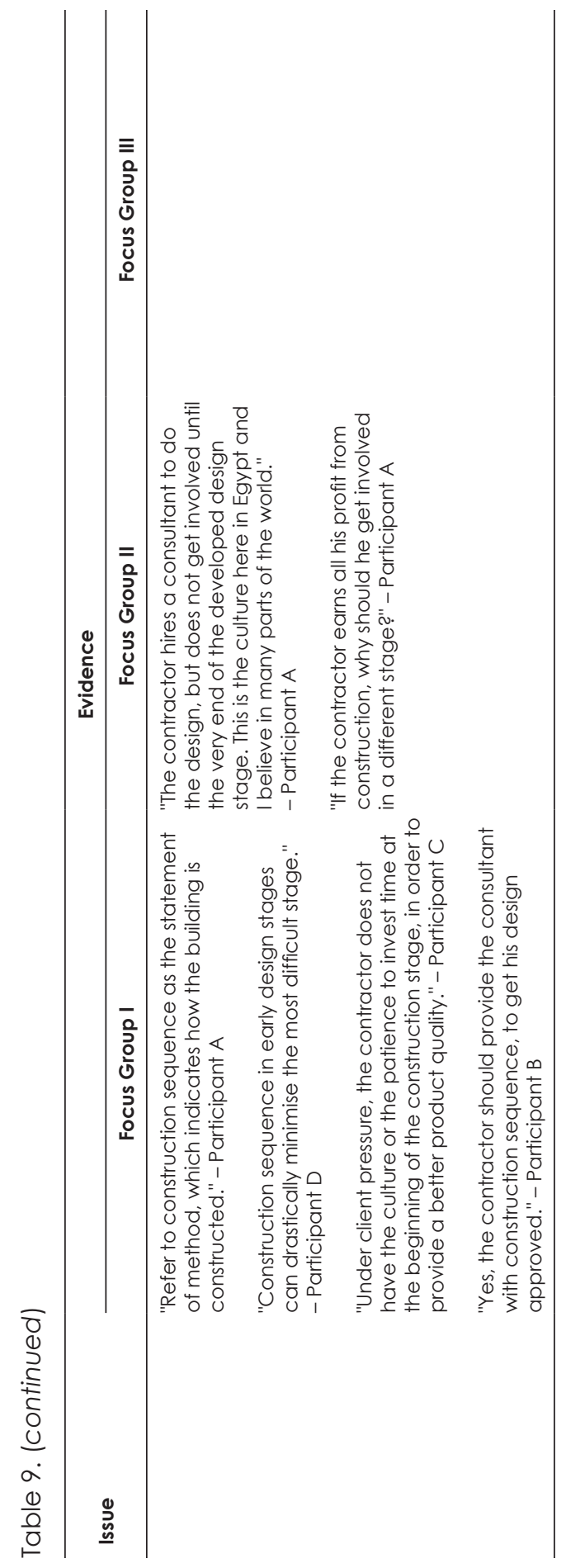


Three main patterns of information identified from the responses of participants are explained in the following sections.

\section{Achieve integration between stakeholders throughout project lifecycle}

Several BIM activities have been identified at each stage in the RIBA PoW lifecycle stages. However, they all seek to achieve a common goal. The implicit goal of identified BIM activities is achieving integration between project stakeholders throughout its lifecycle. The use of parametric design models, 3D visualisation, virtual reality (VR) and 3D laser scanning have been frequently mentioned as collaborative tools, which are able to achieve integration between owners, consultants and contractors. Examples include developing parametric design models to reflect cost information and VR models to visualise design intent for decision makers. This should achieve integration between the owner and architect, in concept design and preparation and brief stages. It has been acknowledged that BIM benefits are still unrecognisable in the stages related to business i.e. strategic definition. All participants of the three focus groups argued that it is imperative that the desired integration takes place as early as possible to be effective. Late involvement of other disciplines usually extends the design stage duration. Eventually the architect will have to satisfy the requirements of other disciplines. This leads to small - but many - changes in the concept design. It was acknowledged that current practices and mindsets in the field form challenges that would inhibit such integration. The project manager or the client should be aware of the benefits of such integration and enforce other stakeholders to share such information. Suggestions have been made to overcome these challenges. However, it was also acknowledged that these suggestions cannot be effective without the presence of mandating governmental policies and more informed clients.

\section{Teaching design coordination}

Developing a coordinated design is one of the identified BIM strategic objectives. Most participants acknowledged that developing a coordinated design is a major challenge in Egypt. Participants stated that the common culture in Egypt is that design coordination is the responsibility of the contractor, even in projects with BIM implementation. Eventually design coordination takes place in the construction stage, leading to much rework, costly design changes, conflicts and a low-quality product. This is the opposite of what the core objective of BIM, which is shifting the peak of information generation into the early design stages (MacLeamy, 2004). Moreover, it was mentioned that people in design firms lack the necessary collaboration skills to manage design coordination. This can be interpreted that practitioners in design firms practise collaboration in BIM projects based on their previous experience from traditional projects. Hence, there should be educational and awareness activities to practitioners in design firms about the development and management of coordinated design. The desired coordination is not mainly related to clash detection. The term "clash-free" model is being marketed as a synonym for coordinated design, although clash detection and clash avoidance are considered to be an integral part of the BIM process (Designing Buildings Ltd., 2017). A clashfree design model can still contain many buildability and maintainability issues that can change the concept design. This emphasises the necessity of early integration 
of contractors in the design process, due to the lack of knowledge related to buildability in design firms. Worth to mention that the teaching of coordinated design theme was identified in Focus Group I and Focus Group II, whose participants were mainly of mechanical and electrical engineering backgrounds, unlike the participants of Focus Group III which comprised participants with architectural and BIM consultancy backgrounds. This can be interpreted to acknowledging that MEP disciplines are the most affected by uncoordinated designs. An identified sub-theme related to teaching design coordination, is the sustainability of project information model for reusability throughout project lifecycle. Current practices imply scrapping design models of each stage and starting the modelling processes from scratch. Developing a coordinated design should significantly sustain the project information model, to be reused in technical design, construction and inuse stages, since that these carried out tasks in these stages would be enriching BIM models with non-graphical information.

\section{Refining current LOD definitions}

All participants argued that the current LOD definitions needed more refinement. The current LOD definition standards contain many flaws and are not really applicable in real world. A common pattern was identified in all discussions. There was a consensus amongst the focus groups that it is impractical to reach the highest level of geometrical detail in construction and as-built models. As an example, most LOD standards indicate the as-built models should be of LOD500, which represents the maximum level of geometrical detail and information. It was acknowledged that the exerted effort is too big compared to the value gained from such graphical detailing. The graphical level of detail of an element should stop at the level that shows how much space an element occupies in space, without further detailing of how that element looks in real life. Suggestions have been made to describe the progression of iLOD of design elements independently from eLOD, throughout project lifecycle stages. In MEP disciplines, after a certain eLod (identified to be eLOD350, based on AIA definition), the increase in level of detail can be compensated by an increase in the level of information. Architectural elements' eLOD can be increased to reach realistic level of detail (eLOD500) in front of house areas, for the sake of visualisations only. Participants of Focus Group III indicated that achieving the level of graphical detail of LOD500 is not possible using current software and hardware capabilities, as it will cause severe performance issues.

As a conclusion, it is not practical to apply a single LOD definition to the whole building model. The LOD definition should be on the level of building model elements and should relate to the element zone, discipline and the current project lifecycle stage. In addition, generally the graphical level of detail should stop at eLOD350, while the level of information should reach iLOD500.

\section{Objective C: The Integration of BIM-RIBA PoW over Traditional Project Lifecycle Stages in Egypt}

Two main themes have been identified. Both table structure and process map structure should be used and there must be a tendering stage in project lifecycle. Table 10 shows the identified common themes through the thematic analysis conducted on Focus Groups' discussion. 
Table 10. Qualitative Analysis Matrix: Research Question 5

\begin{tabular}{|c|c|c|c|}
\hline \multirow{2}{*}{ Issue } & \multicolumn{3}{|c|}{ Evidence } \\
\hline & Focus Group I & Focus Group II & Focus Group III \\
\hline $\begin{array}{l}\text { Table structure } \\
\text { vs. process map }\end{array}$ & $\begin{array}{l}\text { "Process map is better } \\
\text { in describing the } \\
\text { information flow and } \\
\text { roles, however, the } \\
\text { table structure is better } \\
\text { describing what needs } \\
\text { to be done at each } \\
\text { stage, regardless of who } \\
\text { will do it. So, an effective } \\
\text { PoW should include } \\
\text { both." - Participant C; } \\
\text { Participant D } \\
\text { "Both structures offer } \\
\text { different levels of detail." } \\
\text { - Participant B }\end{array}$ & $\begin{array}{l}\text { "You cannot use only one, } \\
\text { both must be used." } \\
\text { - Participant A } \\
\text { "I believe that the process } \\
\text { map is better, because the } \\
\text { table structure is unable } \\
\text { to illustrate tasks which are } \\
\text { carried out in more than } \\
\text { one stage." - Participant D } \\
\text { "The table structure is useful } \\
\text { in describing what needs } \\
\text { to be done in general. The } \\
\text { process is more detailed." } \\
\text { - Participant E }\end{array}$ & $\begin{array}{l}\text { "I believe there should } \\
\text { be some combination } \\
\text { between both structures." } \\
\text { - Participant E } \\
\text { "Owner management } \\
\text { does not need more than } \\
\text { to know what needs to } \\
\text { be done at each stage } \\
\text { and therefore, the table } \\
\text { structure is suitable for } \\
\text { them." - Participant A }\end{array}$ \\
\hline $\begin{array}{l}\text { Procurement } \\
\text { task vs. tendering } \\
\text { stage }\end{array}$ & $\begin{array}{l}\text { "Procurement to be an } \\
\text { activity. Just as planning, } \\
\text { it is an activity that is } \\
\text { carried out and updated } \\
\text { several times throughout } \\
\text { project lifecycle." } \\
\text { - Participant A; } \\
\text { Participant D }\end{array}$ & $\begin{array}{l}\text { "For example, the } \\
\text { government in Egypt } \\
\text { does not allow tendering } \\
\text { projects using direct } \\
\text { order procurement. Such } \\
\text { regulations require that } \\
\text { tendering becomes a clear } \\
\text { stage with a start and an } \\
\text { end." - Participant A }\end{array}$ & $\begin{array}{l}\text { "I think it is better to be } \\
\text { stage, with a clear start } \\
\text { and end. Contractors } \\
\text { are usually not straight } \\
\text { forward, so there should } \\
\text { be stage where a price is } \\
\text { settled." - Participant E }\end{array}$ \\
\hline $\begin{array}{l}\text { RIBA PoW stages } \\
\text { vs. traditional } \\
\text { project lifecycle } \\
\text { stages in Egypt }\end{array}$ & $\begin{array}{l}\text { "I would add the pre- } \\
\text { construction stage." } \\
\text { - Participant E } \\
\text { "...should be a stage acting } \\
\text { as a quality gate between } \\
\text { developed design stage } \\
\text { and technical design } \\
\text { stage." - Participant B }\end{array}$ & & \\
\hline
\end{tabular}

\section{Both table structure and process map structure should be used}

The table structure of the RIBA PoW is not a substitute to the process map. Both structures should be used as contractual documents, since both of them are used to describe different levels of detail and different levels of management. The table structure should serve as a general description of what needs to be done, which is suitable for the management representing the owner or the developer. The process map is more advantageous in describing the information flow between project stakeholders and their responsibilities.

\section{The necessity of the presence of a tendering stage in project lifecycle}

Including procurement as continuum throughout project lifecycle is more beneficial due to the current economic condition in Egypt. However, current regulations and practices in Egypt imply the presence of a tendering stage with a clear start and 
end. Distributing procurement on packages throughout project lifecycle is only applicable in design and build projects. A conclusion can be made that a single structure of project stages cannot fit all procurement routes.

\section{Objective D: Recommend Future Research Opportunities}

Table 11 shows the identified common themes through the thematic analysis conducted on Focus Groups' discussion.

Table 11. Qualitative Analysis Matrix: Research Question 6

\begin{tabular}{|c|c|c|c|}
\hline \multirow{2}{*}{ Issue } & \multicolumn{3}{|c|}{ Evidence } \\
\hline & Focus Group I & Focus Group II & Focus Group III \\
\hline \multirow[t]{5}{*}{$\begin{array}{l}\text { More in-depth } \\
\text { research }\end{array}$} & $\begin{array}{l}\text { "I believe the research } \\
\text { should focus on the } \\
\text { operational level, } \\
\text { moving up to strategic } \\
\text { level, not vice versa." } \\
\text { - Participant A }\end{array}$ & $\begin{array}{l}\text { "I believe the areas you } \\
\text { mentioned are very high } \\
\text { level. There should be more } \\
\text { research on lower levels." } \\
\text { - Participant B }\end{array}$ & $\begin{array}{l}\text { "I believe there should be } \\
\text { more research on how BIM } \\
\text { would be beneficial for } \\
\text { business. I haven't seen that." } \\
\text { - Participant B }\end{array}$ \\
\hline & $\begin{array}{l}\text { "The current problem } \\
\text { is that despite there } \\
\text { is an abundance of } \\
\text { information related to } \\
\text { strategic management, }\end{array}$ & $\begin{array}{l}\text { "Yes, future research should } \\
\text { go in-depth into a specific } \\
\text { subject, instead of doing a } \\
\text { research on very general } \\
\text { subjects." - Participant A }\end{array}$ & $\begin{array}{l}\text { "I believe that there are } \\
\text { more research areas to be } \\
\text { explored in the construction } \\
\text { stage with BIM." } \\
\text { - Participant E }\end{array}$ \\
\hline & $\begin{array}{l}\text { there is still so much } \\
\text { to explore in the } \\
\text { organisational and } \\
\text { operational levels." } \\
\text { - Participant C }\end{array}$ & $\begin{array}{l}\text { "However, they are all } \\
\text { theories and there is a } \\
\text { lack of information of } \\
\text { the methodologies of } \\
\text { implementing these } \\
\text { theories." - Participant B }\end{array}$ & $\begin{array}{l}\text { "Developing a constructible } \\
\text { design using BIM is one of } \\
\text { the most critical subjects that } \\
\text { lack the required research." } \\
\text { - Participant C }\end{array}$ \\
\hline & $\begin{array}{l}\text { "Yes, there should be } \\
\text { a research on linking } \\
\text { the engineering } \\
\text { modelling processes } \\
\text { to the construction } \\
\text { sequence." } \\
\text { - Participant D }\end{array}$ & & $\begin{array}{l}\text { "Clash-free term is being } \\
\text { marketed as a synonym } \\
\text { for coordinated design. } \\
\text { However, you can receive } \\
\text { a clash-free model that has } \\
\text { many constructability issues." } \\
\text { - Participant C }\end{array}$ \\
\hline & & & $\begin{array}{l}\text { "For example, facilitating the } \\
\text { communication between } \\
\text { the site team and technical } \\
\text { office." - Participant B }\end{array}$ \\
\hline $\begin{array}{l}\text { More } \\
\text { educational } \\
\text { activities }\end{array}$ & $\begin{array}{l}\text { "People in the industry } \\
\text { must be properly } \\
\text { educated not just } \\
\text { trained on the BIM } \\
\text { software." } \\
\text { - Participant B }\end{array}$ & $\begin{array}{l}\text { "People with design } \\
\text { background are usually } \\
\text { totally unaware of } \\
\text { constructability issues, } \\
\text { which cause many troubles } \\
\text { at the technical design } \\
\text { stage." - Participant A }\end{array}$ & $\begin{array}{l}\text { "Educate BIM to people in } \\
\text { management and how to } \\
\text { convince them with the } \\
\text { benefits of implementing BIM } \\
\text { in their projects." } \\
\text { - Participant A }\end{array}$ \\
\hline
\end{tabular}


Table 11. (continued)

\begin{tabular}{|c|c|c|c|}
\hline \multirow{2}{*}{ Issue } & \multicolumn{3}{|c|}{ Evidence } \\
\hline & Focus Group I & Focus Group II & Focus Group III \\
\hline $\begin{array}{l}\text { More } \\
\text { collaboration } \\
\text { between } \\
\text { academic } \\
\text { research and } \\
\text { industry pioneers }\end{array}$ & & $\begin{array}{l}\text { "The 'how' part will not } \\
\text { probably get achieved } \\
\text { based on studies. Industry } \\
\text { practitioners must validate } \\
\text { these theories in real- } \\
\text { life projects and provide } \\
\text { feedback." - Participant D }\end{array}$ & \\
\hline & & $\begin{array}{l}\text { "There should be a lot of case } \\
\text { studies, related to the subject } \\
\text { of early engagement of } \\
\text { consultant and contractor." } \\
\text { - Participant B }\end{array}$ & \\
\hline
\end{tabular}

\section{More focus on the "how" instead of "what"}

Through participants' feedback, the discussion explored the "how" part of achieving the integration of project stakeholders. A common theme has been identified among all participants, which is that people in the industry are fed with researches about BIM definitions, BIM benefits, BIM adoption dynamics and what you can do with BIM. Instead, what the industry currently needs is to focus the research on "how" instead of "what", since theoretical frameworks are not enough to improve performance. More research is required on BIM education, better methodologies and best practices, providing in-depth insights upon improving organisational and operational processes. While the "how" part of the research should be conducted by companies in the field, the research process is slow and not shared to everyone, in addition to not following the scientific research methods. Hence, future collaboration between academic research and practical field is significantly recommended. Eastman et al. (2012) argued that new BIM workflows will stem from trial and error efforts by industry pioneers. Figure 4 depicts different levels of BIM processes based on the firm model by Langford and Male (2001).

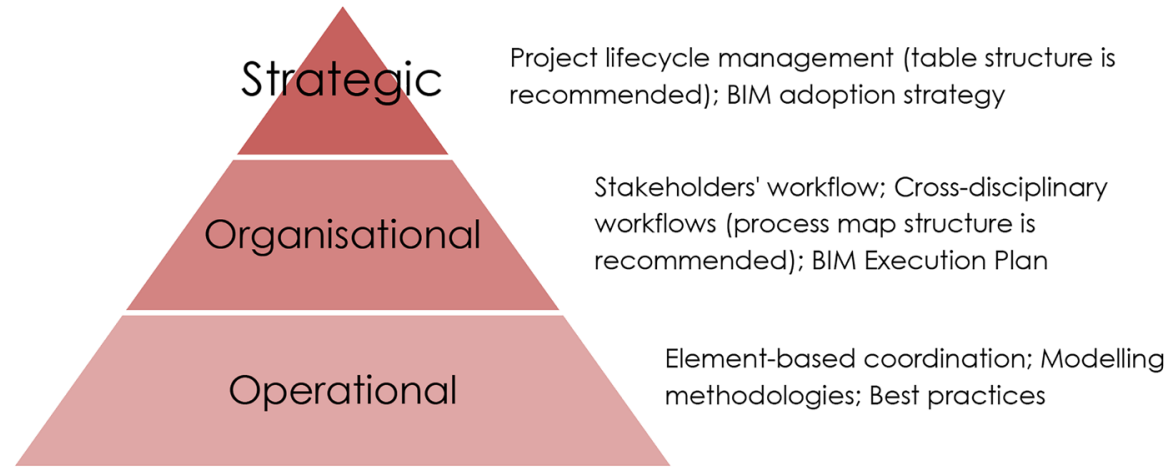

Figure 4. Different Levels of BIM Processes 


\section{More interoperability between BIM tools}

Future research on BIM applications should focus on facilitating the communication between project teams, especially during the construction stage. Furthermore, more research is required on the interoperability between current BIM software, used in the design and construction stages and the software used in facilities management stage. As a conclusion, more integration is required between modelling software and the software used for design calculations.

\section{PROPOSED BIM-RIBA POW FOR EGYPT}

This section explains the discussion made on the identification of the main BIM objectives of each stage in the RIBA PoW, activities, deliverables and recommended educational activities. The section is then concluded with seven which depict the integration of BIM activities with the RIBA PoW.

\section{Strategic Definition}

There has been a consensus acknowledgement that current BIM knowledge cannot do much at this stage. However, the decision to implement BIM in a project should be considered as a cost parameter at this stage. BIM implementation should be considered as an additional preparation. The role of BIM at this stage should be only awareness activities to the people in charge. The awareness activities should be oriented about the real benefits they should expect and when they should begin to see them.

It has been suggested that BIM should facilitate the ability to collect quantitative data from previous projects. However, there has been an acknowledgement that most companies in the construction industry in Egypt are not willing to share information about their project experience. However, a single company can make use of previous projects history.

\section{Preparation and Brief}

Site conditions can significantly impact the concept design and subsequently, impact project feasibility study. Hence, BIM should be used at this stage to model site conditions and integrate this model into the concept design stage. This implies many back and forth movement between the concept design stage and the preparation and brief stage. Hence, it is recommended that both stages are merged into a single stage (as shown in Figure 5). 


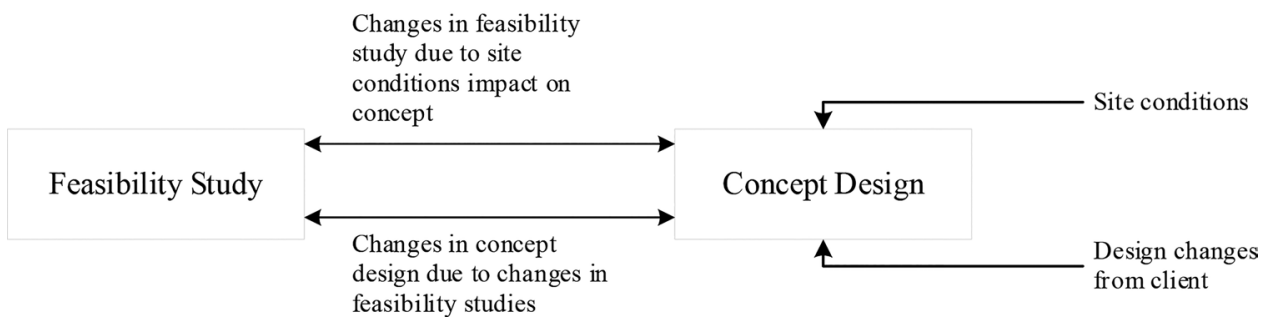

Figure 5. Diagram Showing the Reason Why the Preparation and Brief and Concept Design Should be One Stage

\section{Concept Design}

The main BIM objective at this stage is to facilitate the communication between the designer and the client. Visualisation of design intent at this stage should help obtain clear design decisions with minimum impact on project budget and duration. Considering the large scale of buildings in Egypt and the GCC countries, VR model can be developed only for the front of house areas. BIM should also enable the integration of industry-standards cost information into a parametric concept design model. Site conditions and supply chain capabilities should be integrated into the project as early as the concept design stage. Another objective is to facilitate the involvement of other design disciplines in the concept design stage. The architect should be provided with the engineering requirements to be considered in the concept design. Cost information should be obtained from a parametric design model that is integrated with history cost information from other projects.

\section{Developed Design}

The main problem in the developed design stage is that the resulting design model is not coordinated. The main objective of BIM at this stage is to facilitate the development of a coordinated design model. While people already work in a 3D collaborative environment, they lack the knowledge and skill to collaborate effectively. Their collaborative work experience is based on their previous work in traditional projects. Moreover, the training they receive is usually related only to software skills. Most often, the resulting developed design model is not reusable for the following stages. Hence, the model is implicitly redesigned, but with more timetable pressure. The non-usability of the developed design model is mainly because of poor cross-trade coordination during design progression stages. While current BIM software provides the tools necessary to do cross-trade coordination, people at this stage use their experience from traditional projects to do the coordination in BIM projects. The common culture in Egypt is that the contractor is the entity responsible for the coordination and the designer is only responsible for calculations and 2D layouts. Hence, the BIM model is developed using the same workflows and methodologies of traditional projects. Thus, what needs to be addressed at this stage is how to change this mentality into more collaborative workflows. Another issue usually faced in the developed design stage is the vague definition of the LOD of BIM models. 


\section{Technical Design}

Technical design is considered the most complicated stage in the whole project lifecycle. Based on the quality of the developed design stage output, it could be just a stage of integrating supply chain information or it could lead to an implicit redesign of the whole building. The redesign process usually occurs due to the existence of many coordination and buildability issues that have not been considered in the developed design. In addition, in most design and build projects, this stage overlaps with the construction stage, making the redesign process under the pressure of concrete pumps and project timetable. This eventually leads to low quality output and many site-based decisions that heavily impact the performance of the building. Technical design stage should contain sufficient information about construction sequence and construction methods. Moreover, BIM should facilitate the coordination between procurement plans and construction sequence (4D model).

\section{Construction}

The main complication at this stage is that BIM practically ends before it. Most site engineers and workers still depend on printed shop drawings to perform building and installation processes. What happens is that printed drawings usually do not contain enough information and shows only information related to a single trade. This leads to many questions at the site team, on why certain things are built in certain way and not the other. Subsequently, this leads to many debates between the site team and technical office and -in many cases- on-site design change decision. The main objective of BIM at this stage is to provide a platform that enables the site team to navigate through the design model, place mark-ups, comments and obtain clarifications on real-time basis. In addition, BIM should be of great help to manage site logistics and storage, by integrating 4D models with procurement requirements and constraints.

\section{Handover}

There has been a consensus agreement that there is no specific task for BIM at the Handover stage. The Handover stage is considered as a preparation for the in-use stage. However, there should be a "lessons learnt" stage at the end of each project, in which BIM should help translate project successes and failures into measurable numbers.

\section{In-Use}

Currently COBie is the common deliverable in the In-Use stage; however, it would be better to integrate COBie into a 3D model using a 3D model-based FM software. There is currently some FM software systems that are 3D model-based, however, there are still many interoperability issues between them and the BIM software used in design construction (as shown in Table 11). 

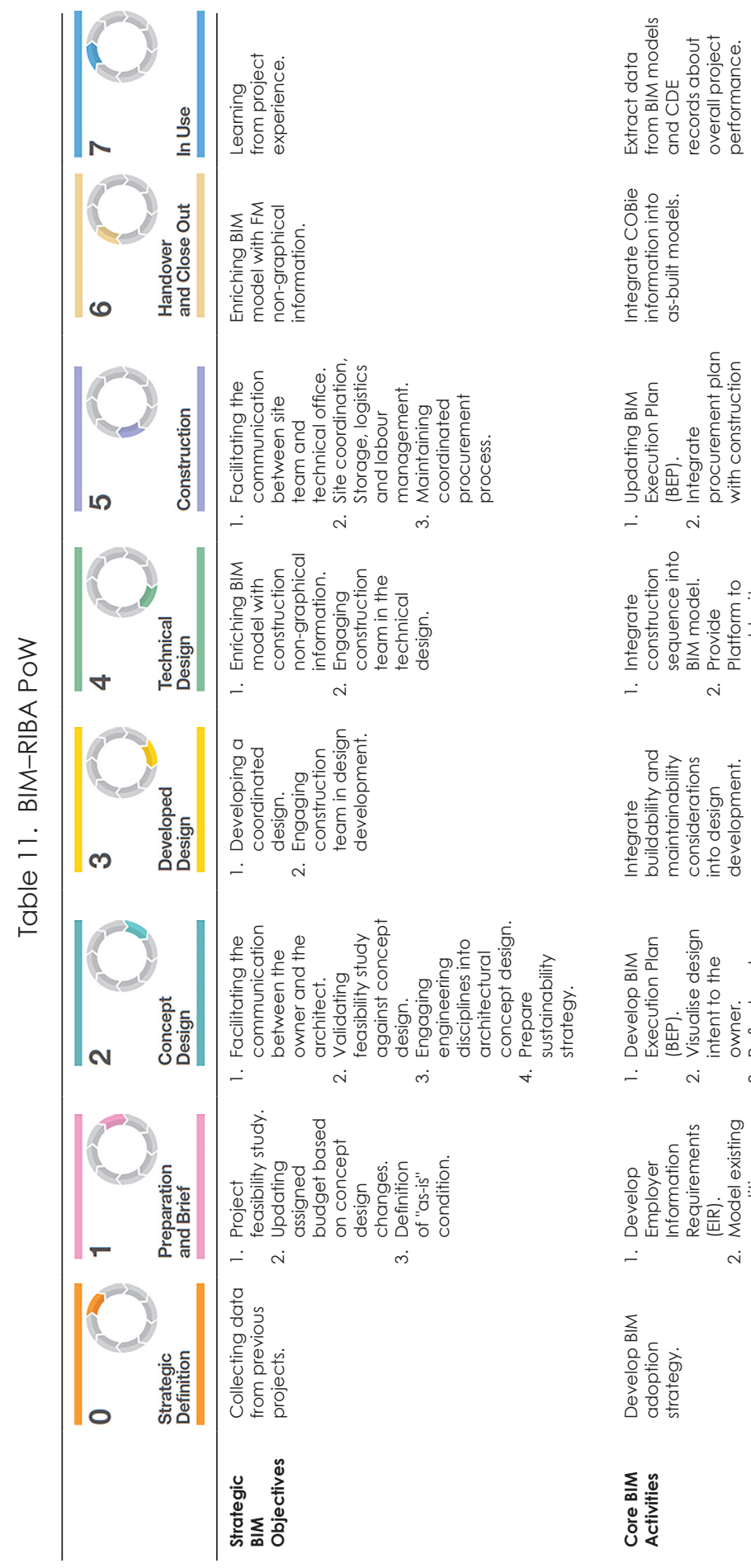

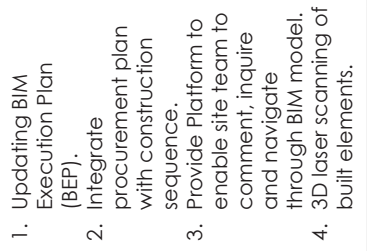

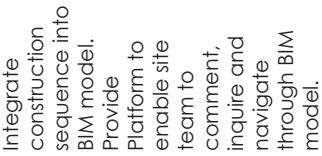

$\therefore \quad r$

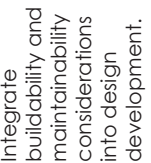
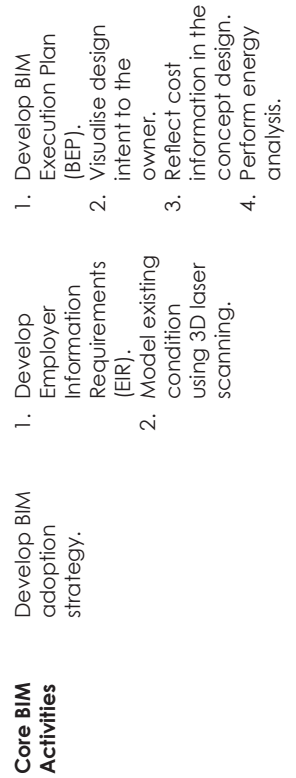


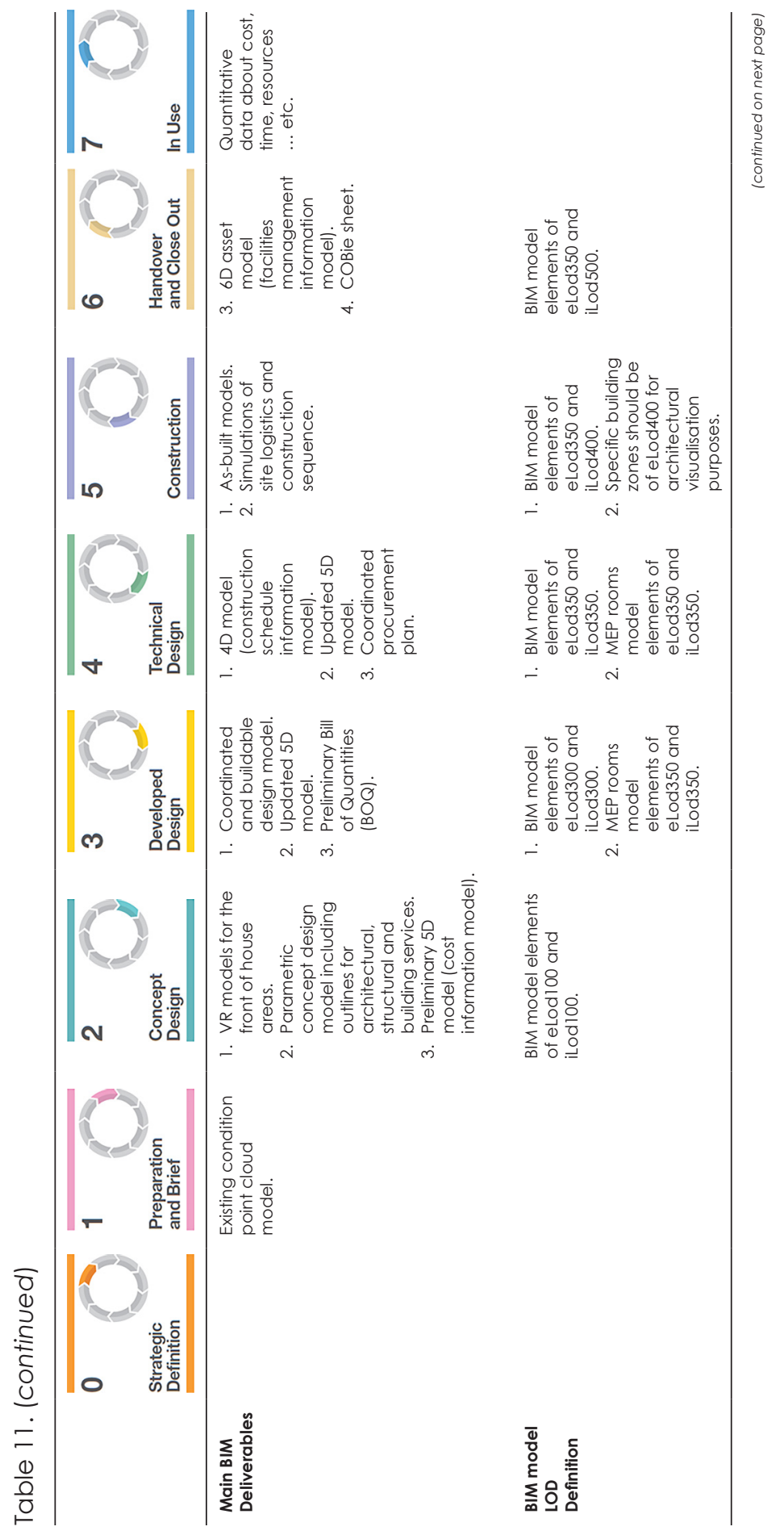



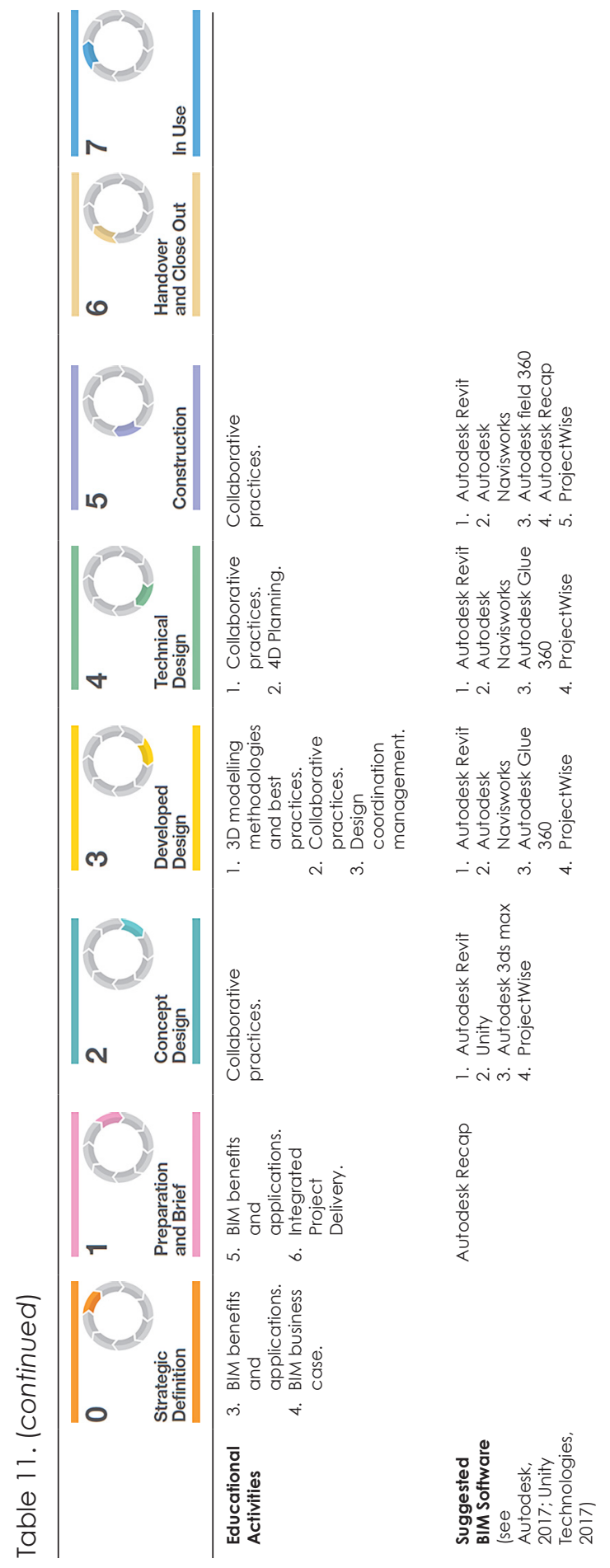


\section{CONCLUSION}

This research was conducted to investigate the integration of a BIM-RIBA PoW for delivering construction projects in Egypt. The research aim was achieved through literature review and collecting qualitative data from industry practitioners. Qualitative data were collected through focus group interviews, conducted in Cairo, Egypt. Collected data were then analysed through consecutive stages of audio-recording, transcription, coding, structuring. Analysed data were interpreted using grounded theory approach, into a theoretical framework, depicting the integration of different BIM activities into the RIBA POW. The devised PoW was then put into contrast with traditional project lifecycle stages in Egypt to identify the pros and cons of each methodology.

This research explored the opinions of practitioners representing business, design and construction backgrounds. The benefits and challenges of integrating the RIBA PoW in Egypt have been explored. The BIM-RIBA PoW has been devised based on construction practices in Egypt. Focus groups discussion yielded other necessary themes for successful BIM adoption in Egypt such as teaching design coordination, refining current LOD definitions and the necessity of governmental BIM mandating policies. However, as a limitation there has been a difficulty reaching personnel with considerable experience in the facilities management domain. Hence, identified BIM objectives and deliverables are based on the expectations and assumptions of participants representing other domains.

\section{APPENDIX}

\section{Appendix 1: Focus Group Questions}

The questions from no. 1 to 6 were used to collect data, based on the research objectives. For information on research objectives:

1. What are the benefits and challenges of integrating the RIBA PoW as a standard construction project lifecycle process in Egypt?

a. Identify the benefits of integrating the RIBA PoW.

b. Identify the challenges faced when integrating RIBA PoW into current construction practices in Egypt.

2. What should be the strategic BIM objectives at each stage of the RIBA PoW?

a. Identify the complications of each project lifecycle stage e.g. the high uncertainty level at the concept design stage.

b. The solutions to these complications will be identified as the main BIM objectives. 
3. Based on the identified objectives, what should be the main BIM deliverables of each stage of the RIBA PoW?

a. How can BIM achieve the identified objectives?

b. Use LOD to describe BIM model progression throughout project lifecycle.

4. Based on the developed BIM-RIBA PoW, describe the workflow between project main stakeholders? At which stage should each stakeholder be involved and what should be the contribution?

a. Introduce Integrated Project Delivery (IPD).

b. Based on IPD concept, at which stage should each stakeholder get involved in the project and to which extent?

5. How can the developed BIM-RIBA PoW be overlaid over the traditional project lifecycle in Egypt?

a. Introduce the traditional project lifecycle in Egypt.

b. Put RIBA PoW in contrast with the traditional project lifecycle and investigate the advantages of integrating both.

6. What are the potential areas to be researched in the BIM process field?

\section{REFERENCES}

Abanda, F.H. and Tah, J.H.M. (2014). Open source Building Information Modelling for developing countries. Paper presented at the 6th Annual International Conference on ICT for Africa. Yaoundé, Cameroon, 1-4 October.

Abanda, F.H., Vidalakis, C., Oti, A.H. and Tah, J.H.M. (2015). A critical analysis of Building Information Modellin systems used in construction projects. Advances in Engineering Software, 90: 183-201. https://doi.org/10.1016/j. advengsoft.2015.08.009.

Abdel-Razek, R.H. (1998). Factors affecting construction quality in Egypt: Identification and relative importance. Engineering, Construction and Architectural Management, 5(3): 220-227. https://doi.org/10.1108/eb021076.

Abdul-Rashid, I., Bassioni, H. and Bawazeer, F. (2007). Factors affecting safety performance in large construction contractors in Egypt. In D. Boyd (ed.), Procs. 23rd Annual ARCOM Conference. Belfast: Association of Researchers in Construction Management (ARCOM), 661-670.

Abubakar, M., Ibrahim, Y.M., Kado, D. and Bala, K. (2014). Contractors' perception of the factors affecting Building Information Modelling (BIM) adoption in the Nigerian construction industry. Proceedings: 2014 International Conference on Computing in Civil and Building Engineering. Virginia: American Society of Civil Engineers (ASCE). https://doi.org/10.1061/9780784413616.022.

Ahmad, M.A., Demian, P. and Price, A.D.F. (2012). BIM implementation plans: A comparative analysis. In S.D. Smith (ed.), Procs. 28th Annual ARCOM Conference. Edinburgh: ARCOM, 33-42. 
Arayici, Y., Coates, P., Koskela, L., Kagioglou, M., Usher, C. and O'Reilly, K. (2011). BIM implementation and adoption process for an architectural practice. Structural Survey, 29(1): 7-25. https://doi.org/10.1108/02630801111118377.

Arayici, Y., Egbu, C. and Coates, P. (2012). Building Information Modelling (BIM) implementation and remote construction projects: Issues, challenges and critiques. Journal of Information Technology in Construction, 17: 75-92.

Autodesk (2017). Architecture, Engineering and Construction Collection. San Rafael, CA: Autodesk. Available at: https://www.autodesk.com/collections/ architecture-engineering-construction/overview [Accessed on 20 September 2017].

Azhar, S. (2011). Building Information Modeling (BIM): Trends, benefits, risks and challenges for the AEC industry. Leadership and Management in Engineering, 11 (3): 241-252. https://doi.org/10.1061/(ASCE)LM.1943-5630.0000127.

Bank Audi (2016). Egypt Economic Report. Beirut, Lebanon: Bank Audi. Available at: http://www.bankaudi.com.eg/Library/Assets/EgyptEconomicReport-2016English-040615.pdf [Accessed on 3 June 2017].

British Standards Institution (BSI) (2014a). BS 1192-4:2014 Collaborative Production of Information. Fulfilling Employer's Information Exchange Requirements using COBie. Code of Practice. London: BSI. Available at: https://shop.bsigroup. com/forms/PASs/BS-1192-4-2014/ [Accessed on 6 July 2017].

. (2014b). PAS 1192-3:2014 Specification for Information Management for the Operational Phase of Assets Using Building Information Modelling. London: BSI. Available at: https://shop.bsigroup.com/forms/PASs/PAS-1192-3-2014/ [Accessed on 6 July 2017].

. (2013). PAS 1192-2:2013 Specification for Information Management for the Capital/Delivery Phase of Construction Projects Using Building Information Modelling. London: BSI. Available at: http://shop.bsigroup.com/forms/PASs/ PAS-1192-2 [Accessed on 1 July 2017].

Bui, N., Merschbrock, C. and Munkvold, B.E. (2016). A review of Building Information Modelling for construction in developing countries. Procedia Engineering, 164: 487-494. https://doi.org/10.1016/j.proeng.2016.11.649.

Building Information Modelling (BIM) Task Group (2013). Building Information Modelling: The digital Plan of Work and assemblies. Available at: http://www. bimtaskgroup.org/wp-content/uploads/2013/02/BIM-The-Digital-Plan-ofWork-v7-1.pdf [Accessed on 1 July 2017].

Cheng, J.C.P. and LU, Q. (2015). A review of the efforts and roles of the public sector for BIM adoption worldwide. Journal of Information Technology in Construction, 20: 442-478.

Construction Industry Council (CIC) (2013). Building Information Model (BIM) Protocol. London: CIC.

Cousins, S. (2016). Is There Any Quantifiable Evidence for BIM's Benefits? London: Chartered Institute of Building. Available at: http://www.bimplus.co.uk/ people/there-any-quan5tifiable-e4vidence-bi5ms-benefits/ [Accessed on 29 June 2017].

Creswell, J.W. (2014). Research Design: Qualitative, Quantitative and Mixed Methods Approaches. Thousand Oaks, CA: SAGE Publications, Inc.

Designing Buildings Ltd. (2017). Design coordination. Available at: https://www. designingbuildings.co.uk/wiki/Design_coordination [Accessed on 24 September 2017]. 
Dar Al-Mimar Group (DMG) (2011). Together for a better life. Available at: http:// www.dmg.com.eg/?page_id=11 [Accessed on 7 July 2017].

Eastman, C., Teicholz, P., Sacks, R. and Liston, K. (2012). BIM Handbook: A Guide to Building Information Modeling for Owners, Managers, Designers, Engineers and Contractors. Hoboken, NJ: John Wiley \& Sons, Inc.

El-Gohary, K.M. and Aziz, R.F. (2014). Factors influencing construction labor productivity in Egypt. Journal of Management in Engineering, 30(1): 1-9. https://doi.org/10.1061/(ASCE)ME.1943-5479.0000168.

Elyamany, A.H. (2016). Current practices of building information modelling in Egypt. International Journal of Engineering Management and Economics, 6(1): 5971. https://doi.org/10.1504/IJEME.2016.10000727.

Freitas, H., Oliveira, M., Jenkins, M. and Popjoy, O. (1998). The Focus Group, a qualitative research method. WP ISRC No. 010298, Information Systems Research Group (ISRC), Merrick School of Business, University of Baltimore, Baltimore, USA.

Gerges, M., Mayouf, M., Ahiakwo, O., Jaeger, M., Saad, A. and Gohary, T.-E. (2017). An investigation into the implementation of Building Information Modeling in the Middle East. Journal of Information Technology in Construction, 22: 1-15.

Gething, B. (2011). Green Overlay to the RIBA Outline Plan of Work. London: Royal Institute of British Architects (RIBA).

Gov.uk (2015). Doing business in Egypt: Egypt trade and export guide. Available at: https://www.gov.uk/government/publications/exporting-†o-egypt/doingbusiness-in-egypt-egypt-trade-and-export-guide [Accessed on 3 June 2017].

Hardin, B. and Mccool, D. (2015). BIM and Construction Management: Proven Tools, Methods and Workflows. Indianapolis, IN: John Wiley \& Sons, Inc.

Howard, R. and Björk, B.-C. (2008). Building Information Modelling: Experts' views on standardisation and industry deployment. Advanced Engineering Informatics, 22(2): 271-280. https://doi.org/10.1016/j.aei.2007.03.001.

Ibrahim, D.E., Eldaly, H.T. and Halim, A.S.A. (2014). Construction cost reduction procedures for the national housing project in Egypt. Journal of International Academic Research for Multidisciplinary, 2(5): 56-71.

Ibrahim, Y.M., Lukins, T.C., Zhang, X., Trucco, E. and Kaka, A.P. (2009). Towards automated progress assessment of workpackage components in construction projects using computer vision. Advanced Engineering Informatics, 23(1): 93103. https://doi.org/10.1016/j.aei.2008.07.002.

Jung, W. and Lee, G. (2015). The status of BIM adoption on six continents. International Journal of Civil, Structural, Construction and Architectural Engineering, 9(5): 406-410.

Khodeir, L.M. and Mohamed, A.H.M. (2015). Identifying the latest risk probabilities affecting construction projects in Egypt according to political and economic variables. From January 2011 to January 2013. HBRC Journal, 11(1): 129-135. https://doi.org/10.1016/j.hbrcj.2014.03.007.

Kothari, C.R. (2004). Research Methodology: Methods and Techniques. New Delhi: New Age International Publishers.

Krueger, R.A. (1997). Analyzing and Reporting Focus Group Results. California, London and New Delhi: Sage Publications, Inc.

Langford, D. and Male, S. (2001). Strategic Management in Construction. Oxford: Blackwell Science Ltd. 
Machinchick, T. and Bloom, E. (2012). Building Information Modelling Software, Training/Support Services and Project Management/Collaboration: Global Market Analysis and Forecasts. Boulder, CO: Pike Research. Available at: http://www.navigantresearch.com/wp-assets/uploads/2012/05/BIM-12Executive-Summary.pdf [Accessed on 18 August 2017].

MacLeamy, P. (2004). MacLeamy curve. Available at: http://www.msa-ipd.com/ MacleamyCurve.pdf [Accessed on 27 June 2017].

Mehran, D. (2016). Exploring the adoption of BIM in the UAE construction industry for AEC firms. Procedia Engineering, 145: $1110-1118$. https://doi.org/10.1016/j. proeng.2016.04.144.

Naoum, S.G. (2007). Dissertation Research and Writing for Construction Students. Oxford: Butterworth-Heinemann.

Onwuegbuzie, A.J. (2003). Effect sizes in qualitative research: A prolegomenon. Quality and Quantity: International Journal of Methodology, 37(4): 393-409. https://doi.org/10.1023/A:1027379223537.

Onwuegbuzie, A.J., Dickinson, W.B., Leech, N.L. and Zoran, A.G. (2009). A qualitative framework for collecting and analyzing data in focus group research. International Journal of Qualitative Methods, 8(3): 1-21. https://doi. org/10.1177/160940690900800301.

Race, S. (2012). BIM Demystified: An Architect's Guide to Building Information Modelling/Management. London: RIBA Publishing.

Reddy, K.P. (2012). BIM for Building Owners and Developers: Making a Business Case for Using BIM on Projects. Hoboken, NJ: John Wiley \& Sons, Inc.

Reffat, R.M. (2004). Sustainable construction in developing countries. Paper presented at the First Architectural International Conference. Cairo University, Egypt.

RIBA (2013). RIBA Plan of Work 2013: Overview. London: RIBA.

Sakr, D.A., Sherif, A. and El-Haggar, S.M. (2010). Environmental management systems' awareness: An investigation of top 50 contractors in Egypt. Journal of Cleaner Production, 18(3): 210-218. https://doi.org/10.1016/j.jclepro.2009.09.021.

Salama, M., Aziz, H.A.E., Sawah, H.E. and Samadony, A.E. (2006). Investigating the criteria for contractors' selection and bid evaluation in Egypt. In Procs. 22nd Annual ARCOM Conference. Birmingham: ARCOM.

Sameh, S.H. (2014). Promoting earth architecture as a sustainable construction technique in Egypt. Journal of Cleaner Production, 65: 362-373. https://doi. org/10.1016/j.jclepro.2013.08.046.

Sands, J. (2015). The BIM Roadmap. Berkshire, UK: The Building Services Research and Information Association (BSRIA).

Saunders, M., Lewis, P. and Thornhill, A. (2009). Research Methods for Business Students. London: Pearson Education Limited.

Sinclair, D. (2012). BIM Overlay to the RIBA Outline Plan of Work. London: RIBA.

Succar, B. (2009). Building information modelling framework: A research and delivery foundation for industry stakeholders. Automation in Construction, 18(3): 357375. https://doi.org/10.1016/j.autcon.2008.10.003.

Unity Technologies (2017). Unity for VR and AR. San Francisco: Unity Technologies. Available at: https://unity3d.com/unity/features/multiplatform/vr-ar [Accessed on 20 September 2017]. 
Verhagen, W.J.C., Vrught, B., Schut, J. and Curran, R. (2015). A method for identification of automation potential through modelling of engineering processes and quantification of information waste. Advanced Engineering Informatics, 29(3): 307-321. https://doi.org/10.1016/j.aei.2015.03.003.

Virtual Projects (2015). About Us. Cairo: Virtual Projects. Available at: http:// virtualprojects.build/ [Accessed on 7 July 2017]. 